\title{
New particle formation and ultrafine charged aerosol climatology at a high altitude site in the Alps (Jungfraujoch, $3580 \mathrm{~m}$ a.s.l., Switzerland)
}

\author{
J. Boulon ${ }^{1}$, K. Sellegri ${ }^{1}$, H. Venzac ${ }^{1}{ }^{*}$, D. Picard ${ }^{1}$, E. Weingartner ${ }^{2}$, G. Wehrle ${ }^{2}$, M. Collaud Coen ${ }^{3}$, R. Bütikofer ${ }^{4}$, \\ E. Flückiger ${ }^{4}$, U. Baltensperger ${ }^{2}$, and P. Laj ${ }^{5}$ \\ ${ }^{1}$ Laboratoire de Météorologie Physique CNRS UMR 6016, Observatoire de Physique du Globe de Clermont-Ferrand, \\ Université Blaise Pascal, Clermont-Ferrand, France \\ ${ }^{2}$ Paul Scherrer Institut, Villigen, PSI, Switzerland \\ ${ }^{3}$ MeteoSwiss, Aerological Station, Payerne, Switzerland \\ ${ }^{4}$ Physikalisches Institut, Universität Bern, Bern, Switzerland \\ ${ }^{5}$ Laboratoire de Glaciologie et Géophysique de l'Environnement, CNRS UMR5183, Université Joseph Frourier Grenoble 1, \\ Saint Martin d'Héres, France \\ *now at: Weather Measures, Aubière, France
}

Received: 1 April 2010 - Published in Atmos. Chem. Phys. Discuss.: 27 April 2010

Revised: 27 September 2010 - Accepted: 28 September 2010 - Published: 5 October 2010

\begin{abstract}
We investigate the formation and growth of charged aerosols clusters at Jungfraujoch, in the Swiss Alps ( $3580 \mathrm{~m}$ a.s.1.), the highest altitude site of the European EUCAARI project intensive campaign. Charged particles and clusters $(0.5-1.8 \mathrm{~nm})$ were measured from April 2008 to April 2009 and allowed the detection of nucleation events in this very specific environment (presence of free tropospheric air and clouds). We found that the naturally charged aerosol concentrations, which are dominated by the cluster size class, shows a strong diurnal pattern likely linked to valley breezes transporting surface layer ion precursors, presumably radon. Cosmic rays were found not to be the major ion source at the measurement site. However, at night, when air masses are more representative of free tropospheric conditions, we found that the cluster concentrations are still high. The charged aerosol size distribution and concentration are strongly influenced by the presence of clouds at the station. Clouds should be taken into account when deriving high altitude nucleation statistics. New particle formation occurs on average $17.5 \%$ of the measurement period and shows a weak seasonality with a minimum of frequency during winter, but this seasonality is enhanced when the data set is screened for
\end{abstract}

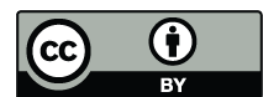

Correspondence to: J. Boulon (j.boulon@opgc.univ-bpclermont.fr) periods when the atmospheric station is out of clouds. The role of ions in the nucleation process was investigated and we found that the ion-mediated nucleation explains $22.3 \%$ of the particle formation. The NPF events frequency is correlated with UV radiation but not with calculated $\mathrm{H}_{2} \mathrm{SO}_{4}$ concentrations, suggesting that other compounds such as organic vapors are involved in the nucleation and subsequently growth process. In fact, NPF events frequency also surprisingly increases with the condensational sink (CS), suggesting that at Jungfraujoch, the presence of condensing vapours probably coupled with high CS are driving the occurrence of NPF events. A strong link to the air mass path was also pointed out and events were observed to be frequently occurring in Eastern European air masses, which present the highest condensational sink. In these air masses, pre-existing cluster concentrations are more than three time larger than in other air masses during event days, and no new clusters formation is observed, contrarily to what is happening in other air mass types.

\section{Introduction}

Aerosols play an important role in the Earth radiative budget through their direct (Charlston et al., 1991) and indirect effect (Twomey, 1974). In fact, the influence of aerosols represents

Published by Copernicus Publications on behalf of the European Geosciences Union. 
the highest uncertainty in understanding and modeling the climatic system and its future evolution (IPCC, 2007). One of the actual challenges in aerosol science is to describe accurately how new particles are formed from gaseous precursors. The formation of secondary new particles have now been studied for several decades, but the degree of our knowledge on the theoretical mechanism (gas - particle conversion), is not sufficient to accurately predict where, when and with which intensity new particle formation events will take place in the real atmosphere. Among other uncertainties, the role of ions or neutral species remains unclear.

Ion-mediated nucleation (IMN) involves the condensation of vapors on positive or negative ions. The attractive potential between ions and ions and between ions and the dipole moment (induced or not) of the condensable vapor reduces the thermodynamic barrier for nucleation and hence, enhances the condensational growth (Lovejoy et al., 2004; Nadykto and Yu, 2004). Conflicting views about the relative importance of IMN subsist between modelling studies (see for example Laakso et al., 2002; Harrisson and Carslaw, 2003; Yu et al., 2008) which assess that IMN should be an important source of atmospheric particles and field measurements (see for example Eisele et al., 2006; Manninen et al., 2009) who show that the contribution of IMN to new particle formation in planetary boundary layer (PBL) is less than $10 \%$ in average. In any case, the charged fraction of clusters and particles is a good indicator of the presence of neutral clusters and particles.

Long-term aerosol measurements in different types of environments is still a valuable approach to better understand which conditions promote the new particle production in the atmosphere. New particle formation events have been observed in various environments (see Kulmala et al., 2004, for a review) from polluted area (Hämeri et al., 1996; Harrison et al., 2000; Woo et al., 2001; Stanier et al., 2004; Dunn et al., 2004) to clean or rural sites (Weber et al., 1997; Mäkelä et al., 1997; O'Dowd et al., 1998; Suni et al., 2008), polar areas (Weber et al., 2003; Asmi et al., 2010) and high altitude sites (Weber et al., 1995; Venzac et al., 2007; Shaw, 2007; Nishita et al., 2008; Rodriguez et al., 2009). It has been recently proposed that nucleation was promoted at high altitude (Venzac et al., 2008). During the day, Jungfraujoch is influenced by injections of air parcels from PBL; Air masses from alpin valleys and the Swiss plateau from lower altitudes are transported to the site by thermal convection (Nyeki et al., 1998). Thus pronounced diurnal cycles are observed for various aerosol parameters (Lugauer et al., 2000). Data acquired in such a site gives valuable information on both the PBL and the FT, but it requires a careful analysis which should take into account the PBL dynamics and the local meteorological parameters such as the frequent presence of clouds which further complicates the picture.

In the present paper, we report and analyze nucleation and new particle formation events detected at the high altitude site Jungfraujoch, located in the Alps ( $3580 \mathrm{~m}$ a.s.l.) dur- ing the EUCAARI (European Integrated project on Aerosol Cloud Climate and Air Quality interactions) intensive observation year 2008-2009 (Kulmala et al., 2009; Manninen et al., 2010).

\section{Methods}

\subsection{Measurements}

Jungfraujoch is situated on the Northly crest in a saddle between the mountains Mönch (4099 m a.s.1.) and Jungfrau (4158 $\mathrm{m}$ a.s.1.), and belong to the glacier accumulation zone. Aerosol measurements were performed at the Sphinx laboratory located on the southern side of the Jungfraujoch at $3580 \mathrm{~m}$ a.s.l. ( $\left.46^{\circ} 32^{\prime} 51^{\prime \prime} \mathrm{N}, 7^{\circ} 59^{\prime} 6^{\prime \prime} \mathrm{E}\right)$, Switzerland, $100 \mathrm{~m}$ below the main crest of the Bernese Alps. Jungfraujoch is a station of the Global Atmosphere Watch (GAW) program. Therefore, among other parameters, the total aerosol number concentration, light absorption and scattering coefficient at various wavelength are routinely measured at the site (Collaud Coen et al., 2007). Additionally, the size distribution between 16 and $570 \mathrm{~nm}$ is measured by a custom built SMPS. Meteorological parameters are monitored at the Swiss National Monitoring Network for Air Pollution (NABEL), located within a horizontal distance of $150 \mathrm{~m}$, at the top of the crest $(3580 \mathrm{~m}$ a.s.1.). The monitored parameters include thirty minute averaged concentrations of $\mathrm{NO}, \mathrm{NO}_{2}, \mathrm{NO}_{\mathrm{x}}$ and $\mathrm{O}_{3}$, and daily averaged concentrations of $\mathrm{SO}_{2}$, aerosol sulfur, and particulate matter with aerodynamic diameter below $10 \mu \mathrm{m}$ (PM10). Neutron measurements were performed on the terrace of the Sphinx laboratory with an IGY neutron monitor which is composed by 18 counter tubes (Flückiger and Bütikofer, 2009).

The campaign dataset is composed of 309 days starting from the 9 April 2008 to the 5 May 2009 with 83 days of interruption due to instrumental failures. The measurements are performed with an instrument which classifies total particles (charged and neutral), and negative and positive atmospheric ions according to their electrical mobility.

\subsection{The Neutral cluster and Air Ion Spectrometer}

The mobility distributions of atmospheric positive and negative ions are measured with a Neutral cluster and Air Ion Spectrometer (NAIS) developed by AIREL Ltd., Estonia (Mirme et al., 2007). This instrument provides alternatively the electrical mobility distribution of both negative and positive ions and of total particles in the mobility range 3.16 to $0.0013 \mathrm{~cm}^{2} \mathrm{~V}^{-1} \mathrm{~s}^{-1}$. The NAIS sampling principle of atmospheric ions of each polarity (negative and positive) is based on the simultaneous selection along two differential mobility analyzers and their subsequent simultaneous detection using 21 isolated electrometers in parallel. The conversion from electrical mobility to diameter is calculated according to the Millikan mobility diameter. For the mean local pressure and 
temperature, the NAIS can collect ions in the diameter range 0.5 to $49 \mathrm{~nm}$.

For the detection of total particles, an additional pair of unipolar charger and electrostatic post-filter were added to the inlet section after the ion offset section of the NAIS device. Particles are charged by ion currents using a corona discharged and analyzed according the same process as the ion measurement mode. The role of the additional electrostatic post-filter is to cut off the concentration of corona ions used to charge the particles in the charger. Previous study defined the limit of the total particle detection down to $\sim 2 \mathrm{~nm}$. Below this size, particles measurements are not relevant since the post-filtering process also filters the sampled newly formed particles (Asmi et al., 2009). The NAIS sampling is performed through a specific inlet (length $=300 \mathrm{~mm}$, diameter $=32 \mathrm{~mm}$, flow rate $=10^{3} \mathrm{~cm}^{3} \mathrm{~s}^{-1}$ ), directly through a window of the station. The design of the inlet was optimized to minimize diffusion losses and ion recombination. The size-cuts of large charged or neutral particles sampled through the NAIS inlet are respectively $10 \mu \mathrm{m}$ and $2 \mu \mathrm{m}$ for wind speeds of $2 \mathrm{~m} \mathrm{~s}^{-1}$ and $5 \mathrm{~m} \mathrm{~s}^{-1}$. As a result, few droplets could enter the inlet, except at wind speed smaller than $5 \mathrm{~m} \mathrm{~s}^{-1}$. This phenomenon could lead to an overestimation of ions number concentration since impaction of droplets could lead to ions production. Furthermore to avoid the freezing of the inlet a heating system was adapted to the inlet, automatically switching on when the temperature was below $0{ }^{\circ} \mathrm{C}$.

The intrument was calibrated at the same time than other instruments (AIS and NAIS) involved in the EUCAARI project before and after the field campaign, where an intercomparison was performed in order check the quality of the measurements. The total particle concentrations measured by NAISs were $\pm 50 \%$ of the reference CPC concentration at 4-40 nm sizes (see Asmi et al., 2009; Gagné et al, 2010).

\subsection{Data analysis}

\subsubsection{New particle formation events classification}

A new particle formation event, as previously described by Dal Maso et al. (2005), must present four criteria: "1. a distinctly new mode of particles must appear in the size distribution, 2. the mode must start in the nucleation mode, 3 . the mode must prevail over a time span of hours and 4 . the new mode must show signs of growth". The classification of event days was performed visually using the daily contour plot of the ion size distribution evolution. Data were first categorized into three main classes: undefined, non-event and nucleation event days. Since different types of nucleation can be observed, event days were classified into different classes (Ia, Ib, II and Bump) according to their quality and their applicability to a growth rate analysis (Hirsikko et al., 2007):

- Ia: continuous growth of clusters $(0.5 \mathrm{~nm})$ to large particle $(\geq 20 \mathrm{~nm})$.
- Ib: these events are not as strong as class Ia events and sometimes cluster or intermediate growth are not clearly visible on the size distribution but the growth rate calculation remains possible.

- II: a clear event is identify but the growth from clusters to large particle is not regular and the shape of the size distribution is unclear. Further analysis of the new particle formation characteristics are complex.

- Bump: a burst of clusters is detected but it is not followed by a significant growth and particle formation. Different explanation are possible such as the total consumption of the condensing vapors or a change in the air mass.

\subsubsection{Growth rates estimation}

The new particle formation process can be described by different steps. Four different boundary diameters (1.3, 3, 7 and $20 \mathrm{~nm}$ ) were determined as representative of different growth steps, as usually chosen for GR calculations (Hirsikko et al., 2005), due to the evolution of growth rates during new particle formation events. Hence the growth could be described as follows: First, the smallest particles $(1.3 \mathrm{~nm})$ concentration increases until a local maximum, then it decreases following a gaussian shape. While this population concentration decreases, the next one $(3 \mathrm{~nm})$ starts to increase until reaching a local maximum etc. The growth rate between two size classes were computed by calculating the time needed to switch from the lower size class local maximum concentration to the nearest higher size class local maximum concentration, as proposed by Hirsikko et al. (2005). In the present work, a normal distribution is fitted to the different size class concentration maxima using a trust-region algorithm (Byrd et al., 1987) by minimizing the least square residues. Thus the growth rate was computed using the fitted parameters as follows $\left(\mathrm{GR}_{x-y}=y-x / t_{0, y}-t_{0, x}\right)$. GRs were computed for class Ia and Ib NPF classes. However, for some class Ib days, the GRs calculation was not possible due to local pollution events, changes in air masses or NPF interruption by clouds. Those days were not taken into account in the growth rate analysis. Furthermore, the effect of coagulation on the size evolution was not included in the GR analysis since its effect is negligible (Manninen et al., 2009).

\subsubsection{Formation rates calculation}

In order to characterize the new particle formation events, it is also important to determine the rate of particles formed during the event, i.e. the formation rate of particles which diameter is of $i \mathrm{~nm}\left(J_{i}\left[\mathrm{~cm}^{-3} \mathrm{~s}^{-1}\right]\right)$, and especially during the first steps of particle's growth, from 2 to $3 \mathrm{~nm}$ (Kulmala et al., 2001). The formation rate can be calculated from particle concentration in the size range from 2 to $3 \mathrm{~nm}\left(N_{2-3}\right)$, the growth rate of $2 \mathrm{~nm}$ particles which is assumed to be the 
same over the whole size class $1.3-3 \mathrm{~nm}\left(\mathrm{GR}_{1.3-3}\right)$ and the loss of particle by coagulation scavenging of $2 \mathrm{~nm}$ particles on larger pre-existing particles $\mathrm{CoagS}_{2}\left[\mathrm{~s}^{-1}\right]$ (Kulmala et al., 2007).

$$
J_{2}=\frac{d N_{2-3}}{d t}+\operatorname{CoagS}_{2} \times N_{2-3}+\frac{f}{1 \mathrm{~nm}} \mathrm{GR}_{1.3-3} N_{2-3}
$$

The formation rate of charged particles in the size range of $2-3 \mathrm{~nm}$, i.e. the charged formation rate $J_{2}^{ \pm}$for both polarity can be calculated from the charged aerosol size distribution obtained from the NAIS. To take into account the loss of ions by ion-ion recombination and the attachment of ions to neutral particles, two terms were added to Eq. (1) :

$$
\begin{aligned}
J_{2}^{ \pm}= & \frac{d N_{2-3}^{ \pm}}{d t}+\mathrm{CoagS}_{2} \times N_{2-3}^{ \pm}+\frac{f}{1 \mathrm{~nm}} \mathrm{GR}_{1.3-3} N_{2-3}^{ \pm} \\
& +\alpha \times N_{2-3}^{ \pm} N_{<3}^{\mp}-\beta \times N_{2-3} N_{<2}^{ \pm}
\end{aligned}
$$

where $N_{2-3}^{ \pm}$is the ion number concentration (positive or negative ions) $\left[\# \mathrm{~cm}^{-3}\right.$ ] in diameter range from 2 to $3 \mathrm{~nm}$ and $N_{<x}^{ \pm}$is the ion number concentration below $x \mathrm{~nm}$. CoagS is the condensation sink of $2 \mathrm{~nm}$ particles $\left[\mathrm{s}^{-1}\right.$ ] (derived for NAIS data), $\mathrm{GR}_{1.3-3}$ is the growth rate for the 1.3$3 \mathrm{~nm}$ size class $\left[\mathrm{nm} \mathrm{h}^{-1}\right.$ ]. $\alpha$ and $\beta$ are respectively the ionion recombination coefficient and the ion-neutral attachment coefficient and were assumed to be equal respectively to $1.6 \times 10^{-6} \mathrm{~cm}^{3} \mathrm{~s}^{-1}$ and $1 \times 10^{-8} \mathrm{~cm}^{3} \mathrm{~s}^{-1}$ (Tammet and Kulmala, 2005). The factor $f$ represents the fraction of the ion population in a size range from 2 to $3 \mathrm{~nm}$ which are activated during the growth. In this study we assumed this factor to be equal to unity. The time derivative of $N_{2-3}$ is directly obtained from the NAIS measurements.

\subsubsection{Air mass analysis}

The impact of the air mass origin and trajectory on the charged aerosol concentration and on the potential of nucleation is studied after calculation of three days air mass back trajectories using the HYSPLIT transport and dispersion model (Draxler and Rolph, 2003). Three days prior sampling were chosen based on the turnover time of aerosol particles, evaluated to be from 1.6-1.7 days for nuclei size ranges, to 2.4 days for $200 \mathrm{~nm}$ particles (Tunved et al., 2005). The calculation is performed over the whole field campaign period every 12 hours at 00:00 and 12:00 Local Time (LT). Since the air mass origin and path to the measurement site do not differ significantly between 00:00 and 12:00, only results for 00:00 will be included in our analysis (Fig. 6).

\section{Results}

\subsection{Ultrafine charged aerosol climatology}

The yearly median total ion concentration (Fig. 1) presents a diurnal variation pattern. During the night, the concentration of ions is quite stable with a mean concentration of
$678 \# \mathrm{~cm}^{-3}$ for negative ions and $709 \mathrm{~cm}^{-3}$ for positive ones. From 06:00 LT, the concentration of both polarities increase until reaching a maximum of $825 \mathrm{\# cm}^{-3}$ and 875 $\# \mathrm{~cm}^{-3}$ respectively for negative and positive ions at 13:00 LT. Then the concentrations decrease rapidly from 15:00 to 18:00 LT to reach the level of night time.

Baltensperger et al. (1997) showed that diurnal variations of aerosol parameters such as surface area are due to thermally driven vertical exchange. In their article, Lugauer et al. (2000) have demonstrated that during winter the Jungfraujoch is most of time decoupled from the PBL and, during the summer, air from the PBL is transported to the site by thermally driven convection. Zellweger et al. (2000) were more restrictive and showed that during summertime, night time measurements with northwesterly advection are considered to represent FT conditions according to the $\mathrm{NO}_{\mathrm{y}}$ speciation. Another study made by Forrer et al. (2000) confirms the transportation of some gases (e.g. CO) is made by thermally driven vertical transport which occurs during daytime. Finally, night time measurements from 03:00 to 09:00 were considered representative of FT conditions for Jungfraujoch (Weingartner et al., 1999) but also for other high altitude sites in Europe (puy de Dôme, Venzac et al., 2007, and high altitude Himalaya, Venzac et al., 2008). Here, we calculated the diurnal variation of $\mathrm{CO}, \mathrm{CS}$, neutron flux and wind direction and speed averaged over the measurement period (Fig. 2). The clear diurnal variation of the CO concentrations and CS with a maximum at mid-afternoon and the positive correlation between these two variables $(r=0.7373)$ confirms the influence of the PBL at the measurement site during the day. This is also confirmed by the typical wind pattern of valley breezes shown on Fig. 2c. Considering the pre-cited studies and the diurnal variation of aerosol and $\mathrm{CO}$ concentrations, CS and wind direction observed at Jungfraujoch over the measurement period, the data set has been segregated into two sub data sets composed of night time measurements on one hand, and day time measurements (from 09:00 to 18:00 LT) on the other hand.

The total ion concentration measured at night (Fig. 1) can be considered as a FT ion nighttime background, while the increase of ion concentrations during the day is likely due to advection of ions or ion sources from the planetary boundary layer. Ions are classified in three different size classes: the cluster ions from 0.5 to $1.8 \mathrm{~nm}$, intermediate ions from 2.1 to $6.8 \mathrm{~nm}$, and large ions from 8 to $47 \mathrm{~nm}$.

Clusters are considered as embryos for new particle formation and growth, they are found to be ubiquitous in the atmosphere (Kulmala and Kerminen, 2008), intermediate ions concentrations usually increase only when a NPF is occurring (see Venzac et al., 2007, 2008), lastly large ions can be disconnected from the new particle formation events and be linked to external incoming of polluted air parcels. Total ion concentrations are dominated by the cluster ions concentrations, which drive the observed diurnal variations. The known sources of ions are either radioactive species such as 


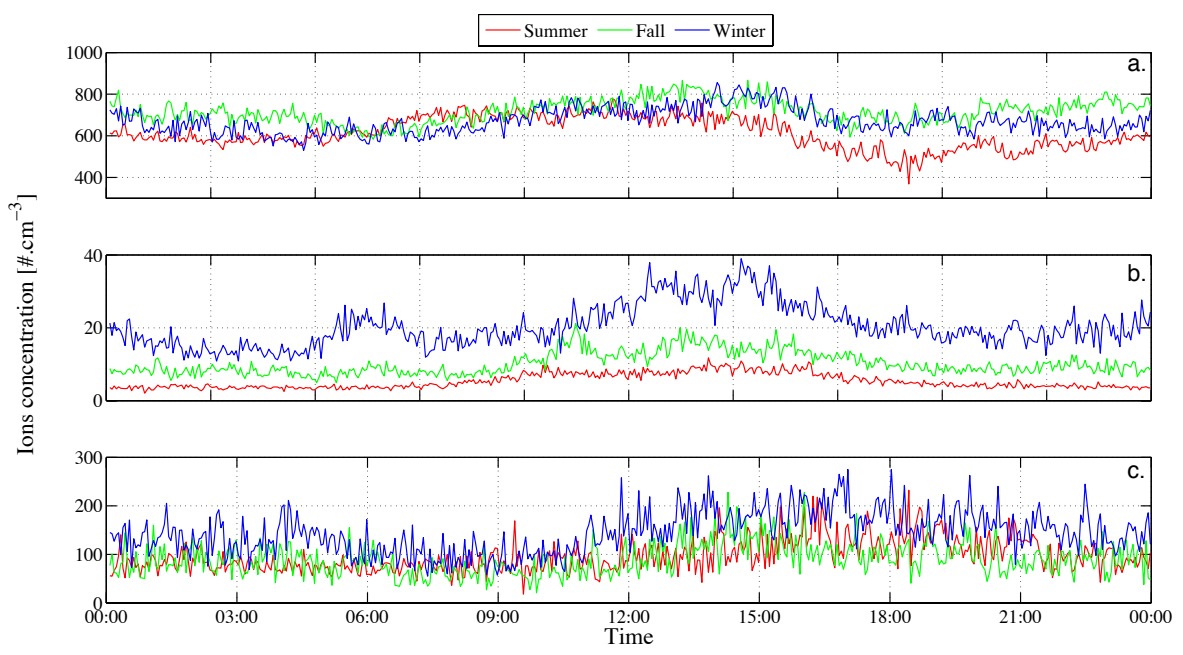

Fig. 1. Median diurnal variation of positive ion size class concentrations from July 2008 to April 2009. (a) Cluster ions, (b) Intermediate ions and (c) Large ions. Summer: July-September 2008, Fall: October-December 2008, Winter: January-March 2009.

radon, or cosmic rays (CR). Due to the local cosmic rays anisotropy, regular daily variations of the CR flux is estimated to be on average 1\% (Usoskin and Kosvaltsov, 2008). Other variations of CR fluxes could be more important but on timescales larger than the day. As a proxy of atmospheric ionization and CR flux we analyse the neutron flux using neutron counter measurements (Aplin et al., 2005). The observed diurnal variation of neutron flux during this field campaign was $0.16 \%$. Since the observed diurnal variation of charged cluster concentrations (average 22.5\%) is higher than the one of CR flux proposed by Usoskin and Kosvaltsov and higher than the diurnal variation of neutron flux measured during the field campaign, we assumed that cosmic rays are not the major ion source at the measurement site and that radiocative species such as radon is mainly responsible of the ion production at this altitude. In the PBL, previous studies of ion diurnal variations showed that radon is the main ionizing agent responsible of the cluster ion formation (Hõrrak et al., 2003). Gäggeler et al. (1995) showed that radon concentration at Jungfraujoch is dominated by transport and not by local production since the ground is most of time covered by snow. According to those previous results and to the diurnal PBL injection of air parcels at the measurement site (Figs. 1 and 2), we can assume that the diurnal variation of the cluster ions concentration is mainly due to the vertical transport of high radon concentration air parcels from the planetary boundary layer during the day and to atmospheric ionization from galactic cosmic rays (GCR) or residual radon during the night. However, a deeper study is needed to investigate the respective role of radon and GCR in ions formation at this site using direct correlations.

A weak seasonality of total ions concentration, largely dominated by clusters, was found, opposing high concentrations during fall and winter (no significant difference be- tween them) to low concentrations during summer (Fig. 1). This result is in agreement with the analysis performed by Weingartner et al. (1999) who pointed out that $10-18 \mathrm{~nm}$ total particles concentrations showed a maximum during wintertime. A closer look at the diurnal variation of cluster ions shows that summertime cluster ions are lower than winter time cluster ion concentrations especially during the 15:00 24:00 time range. Hence, it is likely that the high concentrations of larger particles drifted up the station during summertime around this time of the day represent a significant condensational sink for the cluster ions.

The seasonal variation of intermediate ions is also showing a minimum for summer time. During winter, intermediate ions strongly peak between 12:00 and 15:00. This peak could be linked to the presence of clouds, which effects will be studied in the following section.

\subsection{Cloud effects}

Clouds are known to have a significant effect on ion clusters and intermediate ion concentrations and on NPF occurrence (Venzac et al., 2007; Lihavainen et al., 2007). Consequently, we chose to further separate potential cloudiness conditions from clear sky conditions and analyze them separately to better characterize the cloud effect on aerosol. Unfortunately, LWC measurements were not available during the field campaign, and we used RH data to segregated in-cloud from outof-cloud conditions. The limit value of RH used to distinguish out-of-cloud and in-cloud conditions (i.e. $\mathrm{RH} \geq 96 \%$ ) was validated using LWC data for the puy de Dôme station and Nepal station (unpublished data). Mean and median ion concentration variations are reported on Fig. 3. In order to determine if differences are statistically significant between our sub-classes (nighttime/daytime, in-cloud/out-of- 

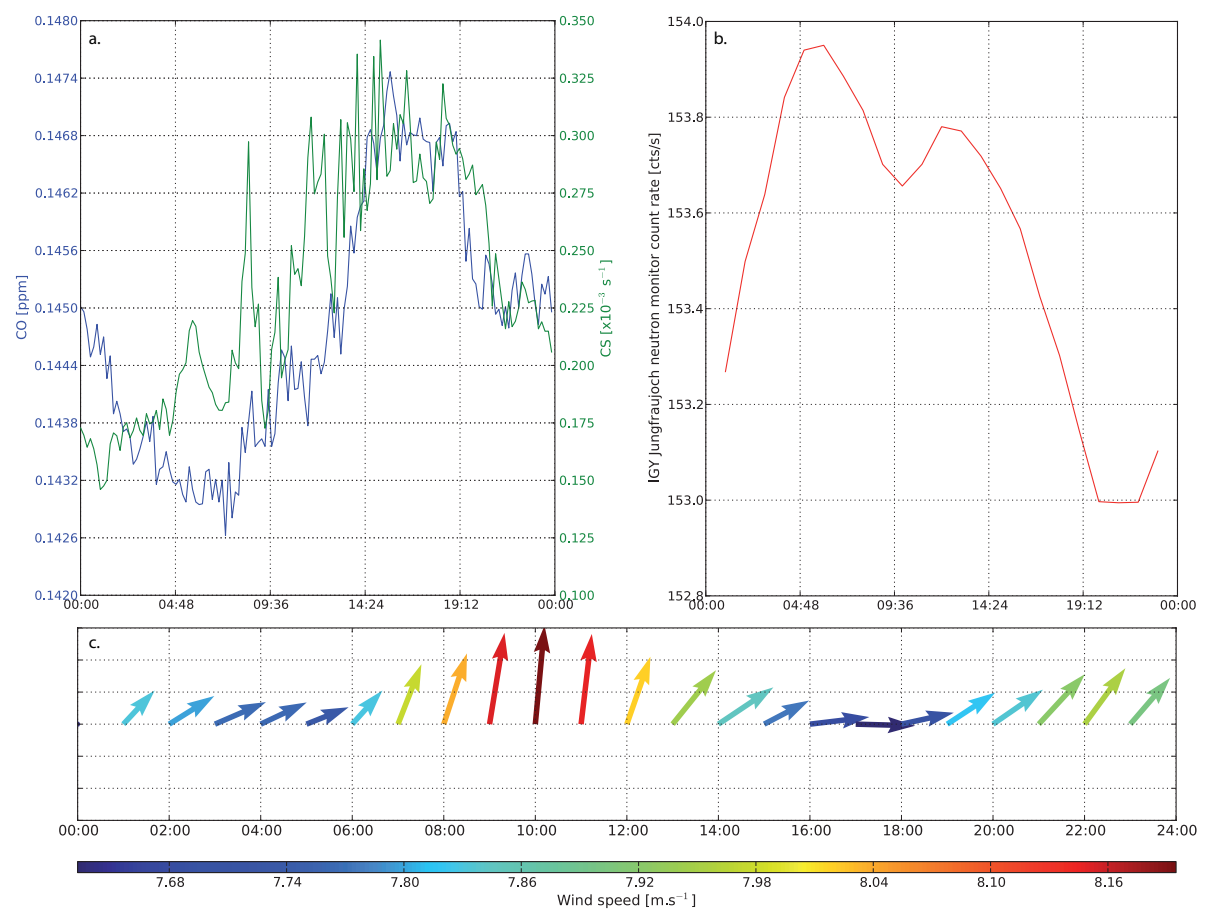

Fig. 2. (a) Mean diurnal variation of carbon monoxide (blue) and condensational sink (green) (left panel), (b) neutron monitor count rate (red) (right panel) and (c) wind direction and speed (bottom panel).

cloud, positive/negative polarity), a T-test was performed on the data set (Table A2). For the cluster size classes, ion concentrations decrease by a factor of 1.5 to 2.5 when the conditions change from out-of-cloud to in-cloud (Fig. 3a). Intermediate ions concentrations are, on the contrary, surprisingly increased by the presence of a cloud, especially for the negative ions. The effect of clouds that we observe on cluster ions is in agreement with the results reported by Venzac et al. at the puy de Dôme station (Venzac et al., 2007) and Lihavainen et al. (2007), who argue that the cloud is a powerfull scavenger for cluster ions. Cloud effects on intermediate ions, however, are different according to the measurement site : in clouds, the intermediate ion concentrations decrease at the PBL forest site of Hyytiälä (Lihavainen et al., 2007), but remain unchanged at the altitude site of puy de Dôme (Venzac et al., 2007) and increase at the high altitude site of Jungfraujoch (this study). Further studies are necessary to understand this phenomenon especially the role of cloud microphysics, which should be investigate deeper.

Concerning the large ion mode, as expected for this size, negative and positive ion population are close to equilibrium under clear sky conditions. In the presence of a cloud, the two populations are increased by a factor $1.4(41 \%)$ and 1.2 (20\%) respectively for positive and negative ions. Figure $3 \mathrm{~b}$ is showing the mean ion concentrations (as opposed to the median ion concentrations shown Fig. 3a). The mean out-ofcloud concentrations are not significantly different from the median concentrations. However, the in-cloud mean ion con- centrations are different from median in-cloud ion concentrations, indicating that intense sporadic events are taking place under cloudy conditions. From the comparison between median and mean ion concentrations in cloud, we conclude that cloud conditions favor the production of sporadic high concentrations of cluster and intermediate ion positive and especially negative ions.

Clouds have a complex effect on ions, particles and gas concentrations. Consequently, in order to understand the impact of other parameters on nucleation and NPF, it is important to segregate in-cloud from out-of-cloud conditions at altitude sites. This will be done in the following sections.

\subsection{New particle formation event analysis}

\subsubsection{Event statistics}

The 309 days of data were analyzed and classified into event, non-event and undefined days (Sect. 2.2.1). Undefined days ( 25 days) represent only $8.1 \%$ of the data, $73.8 \%$ of observed days were classified as non-event days (228 days) and among those days, $59 \%$ (135 days) were classified as "in cloud" conditions. NPF events were observed on $17.5 \%$ of days (54 days). Monthly statistics are shown on Fig. 4 and class occurrence of NPF event according to Hirsikko et al. (2007) are presented Table 1. New particle formation frequencies present a clear seasonality with a minimum of events during winter and maximum from spring to autumn. The maximum of events occurred in April 2009 (28.6\% of observed 


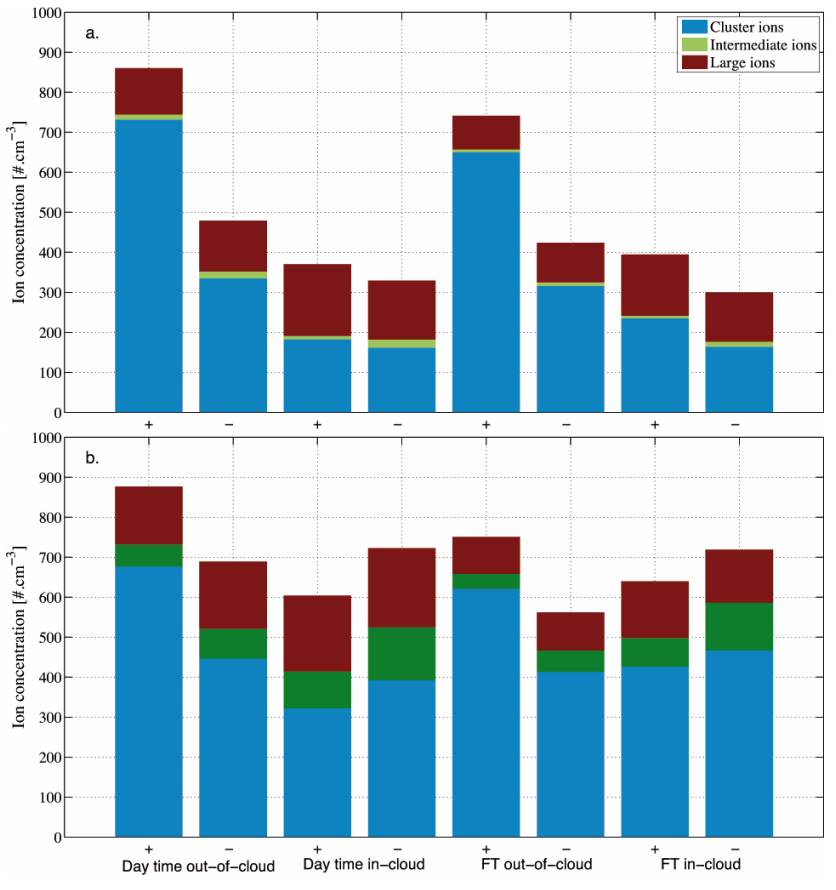

Fig. 3. Yearly median (top panel) and mean (bottom panel) concentration cluster (blue), intermediate (green) and large (red) ion concentrations from July 2008 to April 2009 on daytime and nighttime under clear sky and cloudy conditions.

days present an event) and the minimum during December 2008 (3.6\% of observed days). An especially high frequency of nucleation event (highest number of Ib events) was observed during January 2009. Meteorological parameters and air mass origin analysis do not show significant differences compared to other months. A longer study of nucleation events at Jungfraujoch is needed to statistically characterize this seasonality. At other sites where a NPF events seasonal variation could be studied, the maximal occurrence was usually observed during the spring and autumn seasons as well (Manninen et al., 2010), and during the summer season for altitude sites (Venzac et al., 2008) while the minimal occurrence frequency is always observed during winter (Venzac et al., 2008; Manninen et al., 2010; Boulon et al., 2010). The seasonal variation of the frequency of NPF events is opposite to the seasonal variation of ion cluster concentrations mentioned section 3.1. Hence, the concentration of preexisting cluster ions is not necessarily linked to NPF events at the Jungfraujoch station.

The presence/absence of a cloud during NPF days was checked for all the NPF days and it appears that clouds reach the measurement site during the NPF process for only 4 days ( $7.1 \%$ of NPF observed days). Furthermore, when a cloud occurs during the event the nucleation/growing process is stopped. Considering the low frequency of nucleation during cloudy conditions and the fact that clouds interrupt the
Table 1. Statistics of nucleation events.

\begin{tabular}{lr}
\hline Class of nucleation & Occurrence \\
\hline Ia & 3 \\
Ib & 14 \\
II & 17 \\
Bump & 16 \\
Featureless & 4 \\
\hline
\end{tabular}

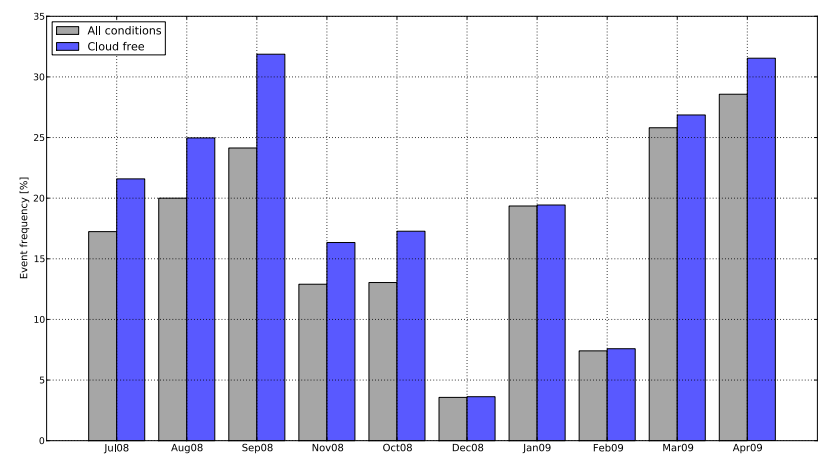

Fig. 4. Monthly frequencies of nucleation/new particle formation events. Grey bars: events according to the total number of days; blue bars: events according to the number of clear sky days.

NPF process we confirm that cloudy conditions inhibit the new particle formation process. This phenomenon has to be linked with 1.- the lack of production of condensable species by photochemical processes, 2 . the scavenging property of cloud droplets which could remove clusters or/and condensable vapors from the atmosphere (Baltensperger et al., 1998) and 3. the significant increase of the CS (due to the high surface area droplets offer for condensing). However, even though clouds seem to affect the frequency of NPF events, they do not drive their seasonal variation. Indeed, the maximum of cloud frequency is observed during summer. Hence, the seasonal variation of the frequency of NPF events is even more pronounced when considering only out-of-clouds conditions (Fig. 4).

Parameters influencing the new particle formation frequency was further investigated considering different atmospheric components such as $\mathrm{H}_{2} \mathrm{SO}_{4}$ concentration, $\mathrm{H}_{2} \mathrm{SO}_{4} / \mathrm{CS}$, UV radiation and UV/CS (Fig. 5). Since no $\mathrm{H}_{2} \mathrm{SO}_{4}$ direct measurements were conducted during the field campaign, we calculated the proxy proposed by (Petäjä et al., 2008) with Hyytiälä's parameters (Eq. 3 where $k=8.8 \times$ $10^{-7} \mathrm{~m}^{2} \mathrm{~W}^{-1} \mathrm{~s}^{-1}$ ). Hence $\mathrm{H}_{2} \mathrm{SO}_{4}$ real concentrations could be very different from our calculations, but their time variations should be respected.

$\operatorname{Proxy}\left(\left[\mathrm{H}_{2} \mathrm{SO}_{4}\right]\right)=k \times \frac{\left[\mathrm{SO}_{2}\right] \times \mathrm{UVB}}{\mathrm{CS}}$

We show that even if a slight positive correlation between $\mathrm{H}_{2} \mathrm{SO}_{4}$ concentrations and nucleation frequency exists $(r=$ 
0.067), this proxy cannot explain the observed nucleation frequency. Furthermore, the nucleation frequency is anticorrelated with $\mathrm{H}_{2} \mathrm{SO}_{4} / \mathrm{CS}$ and UV/CS $(r=-0.419$ and $r=$ -0.227 respectively) and hence positively correlated with the $C S(r=0.471)$. In fact, the strongest correlation is found to be the one with UV radiation alone $(r=0.552)$. Those results suggest that 1 . other compounds than $\mathrm{H}_{2} \mathrm{SO}_{4}$ such as VOCs must be involved in the new particle formation process as previously shown by Laaksonen et al. (2008) and Paasonen et al. (2009) repectively in the boreal forest environment and at a forest high elevation site (Hohenpeissenberg, $980 \mathrm{~m}$ a.s.l.), and in smog chambers by (Metzger et al., 2010), and, 2. the new particle formation process at Jungfraujoch is linked to polluted air parcels incoming since the events are postively correlated with the condensational sink.

\subsubsection{Charged and neutral particle formation rates and the role of ions in nucleation at Jungfraujoch}

Ions significantly contribute to new particle formation events, as previously shown by Arnold (1980); Yu and Turco (2001). In order to quantify the role of ions in the nucleation process at Jungfraujoch, we computed the charged cluster formation rate, the total cluster formation rate and the ion-mediated rate for $2 \mathrm{~nm}$ particle.

The analysis of the $2 \mathrm{~nm}$ charged particle formation rates $\left(J_{2}^{ \pm}\right.$, Table A1) shows that negatively charged particle formation rate is always higher than the one of positive particles whatever the class of event (Ia or Ib). Within the accuracy of the method, the total particle formation rates $J_{2}$ (Eq. 1) were estimated from the data provided by the particle mode of measurement of the NAIS. This was done in order to quantify the importance of the ion-mediated nucleation in this environment. We found that the median $J_{2}$ was 8.8 times bigger than the median $J_{2}^{ \pm}$(Table A1). In other environments such as the boreal forest, $J_{2}$ is at least one order of magnitude bigger than the charged particle formation rate (Manninen et al., 2009). This indicates that ion-mediated nucleation (IMN) is relatively important at Jungfraujoch. In order to investigate the role of ions in nucleation, we have calculated the fraction of IMN according to Eq. (4):

$\mathrm{IMN}=\frac{J_{2}^{+}+J_{2}^{-}+J_{2, \text { rec }}}{J_{2}}$

where $J_{2, \text { rec }}=\delta \times \alpha \times N_{i}^{+} \times N_{i}^{-}$

where $\delta$ is the probability that a collision between two ions of both polarities leads to the formation of a stable neutral cluster (here we assume that $\delta=1$ ), $\alpha$ is the ion-ion recombination coefficient, $N_{i}^{ \pm}$is the concentration of ions which size range were selected in order that the diameter of the resulting neutral diameter was in size range $2-3 \mathrm{~nm}$. IMN shows a large range of values depending of the event day with a median value of $22.3 \%$. Manninen et al. (2010) have computed ion-induced nucleation rate (IIN) which can be derived from Eq. (4), assuming $J_{2, \text { rec }}=0 \mathrm{~cm}^{-3} \mathrm{~s}-1$. IIN contribution to nucleation event at Jungfraujoch is $21.8 \%$. This value is higher than the one computed by Manninen et al. (2009) for the boreal environment suggesting that IIN is more important for nucleation events at Jungfraujoch than at lower altitude sites. The median value of $J_{2}^{+}, J_{2}^{-}$and $J_{2}$ at Jungfraujoch are respectively $0.19,0.28$ and $2.03 \mathrm{~cm}^{-3} \mathrm{~s}^{-1}$. According to Manninen et al. (2010), $J_{2}^{ \pm}$found at Jungfraujoch is similar to the $J_{2}^{ \pm}$computed for many other sites in Europe, while it is the $J_{2}$ found at Jungfraujoch which is significantly lower than the $J_{2}$ found at other places in Europe. The fraction of ion-mediated nucleation is hence higher than at other sites because of the lower neutral nucleation detected at this high altitude site. This finding is conflictual with the results from Mirme et al. (2010) who found no sign of an enhance role of ion-induced nucleation toward the tropopause. It is worth mentioning that our $J_{2}$ calculation is a higher limit, since $3 \mathrm{~nm}$ particles concentrations detected with the SMPS technique were measured to be lower than the $3 \mathrm{~nm}$ particles detected from the NAIS. According to those results, we can assume that ion-mediated nucleation is a significant source of new particle in the troposphere as previously shown by $\mathrm{Yu}$ et al. (2008) for boundary layer conditions.

\subsubsection{Growth rates analysis}

Growth rates were calculated for Ia and Ib events (detailed growth rates and formation rates are reported Table A1).

GR can vary over different size ranges of nanometer sized particles because 1 . the condensable surface do not grow linearly with size and 2. the condensable gases concentrations vary with time (with the intensity of photochemistry for instance). These reasons usually lead the analysis of nanoparticle growth rates to be split in several size ranges. In fact, we found that given the uncertainty on the calculated GR, they do not vary significantly from one size range to the other, but decided to still split our results in usual size ranges for GR calculations. The mean growth rate values for class I events in each size class are $[5.1 \pm 1.7,5.3 \pm 3.5,5.7 \pm 2.2]$ respectively for $1.3-3,3-7$ and $7-20 \mathrm{~nm}$ size classes, showing that the growth was rather constant from 1.3 to $20 \mathrm{~nm}$. No significant differences were found between the class Ia and class $\mathrm{Ib}$ regarding the mean growth rates.

Concentrations of condensable vapors and source rates were calculated from GRs values according to Dal Maso et al. (2002). Gaseous source rates at Jungfraujoch are relatively low $\left(5.12 \pm 3.8 \times 10^{3} \mathrm{~cm}^{-3} \mathrm{~s}^{-1}\right)$ compared to those observed in the boreal forest or in coastal environment (from 1.1 to $52 \times 10^{5} \mathrm{~cm}^{-3} \mathrm{~s}^{-1}$ ). This difference is not surprising since boreal forests and coastal environments are known to house high biological sources of condensable vapours, such as VOC emitted from the vegetation or iodine compounds emitted from exposed sea weed fields.

In Hyytiälä, growth rates are respectively 1.9, 3.6 and $4.2 \mathrm{~nm} \mathrm{~h}^{-1}$ for the size classes $1.3-3,3-7$ and $7-20 \mathrm{~nm}$ 

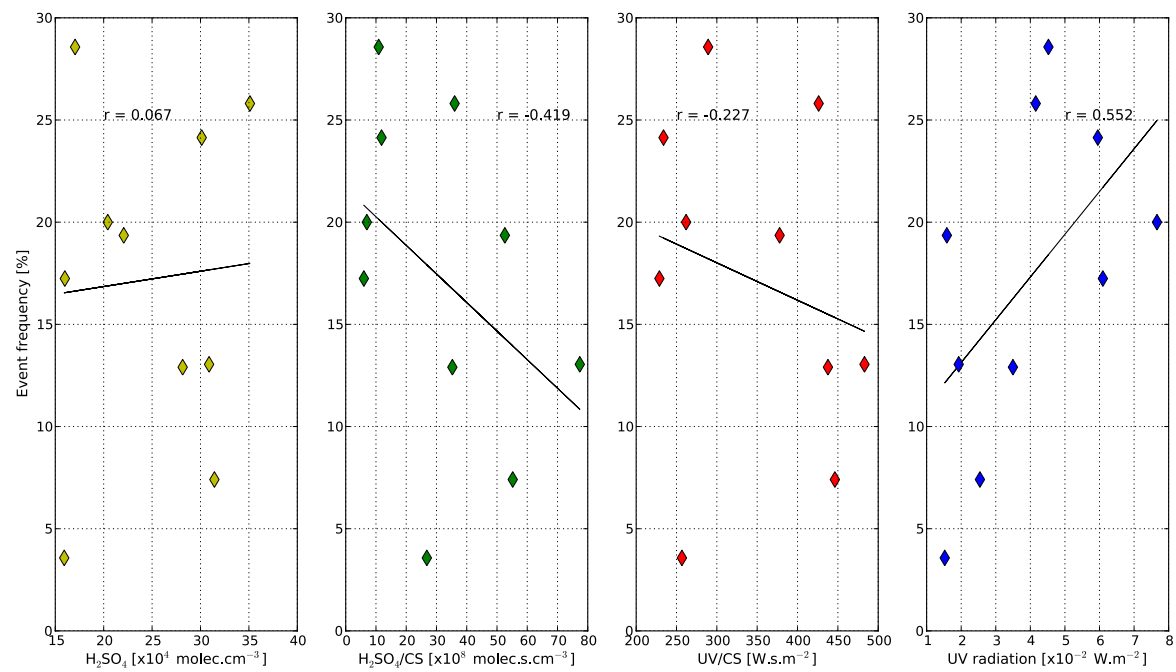

Fig. 5. Relation between events frequency and atmospheric components.

(Manninen et al., 2009). It is surprising that the Jungfraujoch GRs are higher than at a high volatile organic compound (VOC) concentration sites such as the boreal forest. On another hand, the condensational sink $(\overline{\mathrm{CS}}=2.39 \pm$ $1.56 \times 10^{-4} \mathrm{~s}^{-1}$ for all days, and for out-of-cloud conditions $\overline{C S}_{\text {events }}=2.90 \pm 1.12 \times 10^{-4} \mathrm{~s}^{-1}$ and $\bar{C} S_{\text {non-events }}=$ $2.54 \pm 1.52 \times 10^{-4} \mathrm{~s}^{-1}$ ) at Jungfraujoch is so low that even limited concentration of condensable vapours can trigger new particle formation easily. To compare to other sites, this CS value is lower than the one computed by Venzac et al. (2007) for the puy de Dôme altitude station $(\overline{C S}=$ $58 \times 10^{-4} \mathrm{~s}^{-1}$ ) or for the NPO-P station (Venzac et al., 2009; $\overline{\mathrm{CS}}=15.6 \pm 3.6 \times 10^{-4} \mathrm{~s}^{-1}$ ), and according to Manninen et al. (2010), the Jungfraujoch CS value is the lowest of the 12 european EUCAARI measurement sites. The GR calculated in this work differs slightly form the one computed in Manninen et al. (2010) (i.e. $\mathrm{GR}_{1.3-3}=3.7 \mathrm{~nm} \mathrm{~h}^{-1}$ ), due to differences in the calculation methods and to some subjectivity on the choice of the time lap over which the growth is calculated. The difference between the GR calculated in this work and the ones given in Manninen et al. gives an idea of the uncertainty associated to this parameter. Mean values of growth rates for mountain sites present a large scale of variation due to local biogeography. Venzac et al. (2008) have detected NPF events on Everest (5079 m a.s.1.) with an AIS during February-March 2007 and the mean GR value was estimated at $1.8 \pm 0.7 \mathrm{~nm} \mathrm{~h}^{-1}$. Mean value for puy de Dôme is $5 \pm 3.5 \mathrm{~nm} \mathrm{~h}^{-1}$ for the period between March 2006 and December 2007 (Venzac, 2008), at Mt. Norikura, Japan (2770 m a.s.1.), Nishita et al. (2008) have calculated a mean GR value of 2.6-3.1 $\mathrm{nm} \mathrm{h}^{-1}$ between September 2001 and August-September 2002 measurement period. Shaw (2007) reports higher values of GR, $10-23 \mathrm{~nm} \mathrm{~h}^{-1}$, at Mt. Lemmon, Arizona (2790 $\mathrm{m}$ a.s.1.). Those last high values of growth rate are explained by the authors as the result of high organic vapor concentration from desert vegetation associated with high UV-A radiation.

\subsection{Air mass origin analysis}

In this subsection, we investigate the impact of the air mass origin on the occurrence of the new particle formation process. Air masses were classified according to their geographical origin with a resolution of $10^{\circ} \times 10^{\circ}$ (Fig. 6). According to the Hysplit model, all air masses originate from more than $2500 \mathrm{~m}$ a.s.l. but since this model uses as input data meteoroligical variables with $10^{\circ}$ of resolution, it cannot describe local air mass motion such as topographical effects or convection. Assuming that, altitude outputs are overestimated for high altitude sites and can not be discussed in this paper. Five different classes were created depending of the air mass' origin: Atlantic, African, Nordic, Eastern and Western European air masses. Atlantic $(68.5 \%)$ and European continental origin (respectively $6.4 \%$ and $14.2 \%$ for eastern and western Europe origin) represent the highest proportion of air mass origin ending at Jungfraujoch $(89.1 \%)$ followed by african $(7.5 \%)$ and nordic $(3.4 \%)$ air masses. We calculated a new particle formation event frequency for each air mass type (Table 2) and it appears that air mass from Eastern Europe (latitude: $] 40^{\circ} \mathrm{N} ; 70^{\circ} \mathrm{N}$ [ and longitude: [ $20^{\circ} \mathrm{W}$ and more]) have the highest probability to lead to a NPF event, while the lowest probabilities of new particle formation events are found in the air masses from Western Europe (latitude: $40^{\circ} \mathrm{N} ; 70^{\circ} \mathrm{N}$, longitude: $] 10^{\circ} \mathrm{W} ; 20^{\circ} \mathrm{W}$ if latitude $\leq 60^{\circ} \mathrm{N}$, else longitude $10^{\circ} ; 20^{\circ} \mathrm{W}$ ) and Nordic area (latitude $\geq 70^{\circ} \mathrm{N}$ ). This is rather different from the air mass dependencies found in the boreal forest, where nordic air masses were found to favour NPF event as shown by Sogacheva et al. (2005). In the boreal forest where high concentrations of condensable species are 

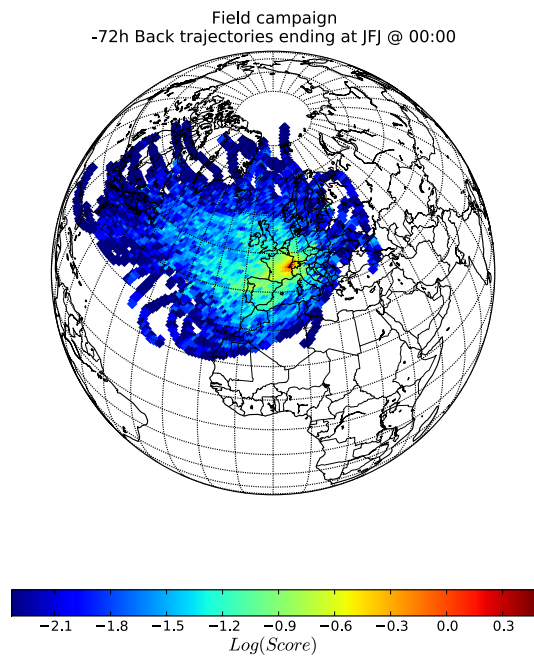
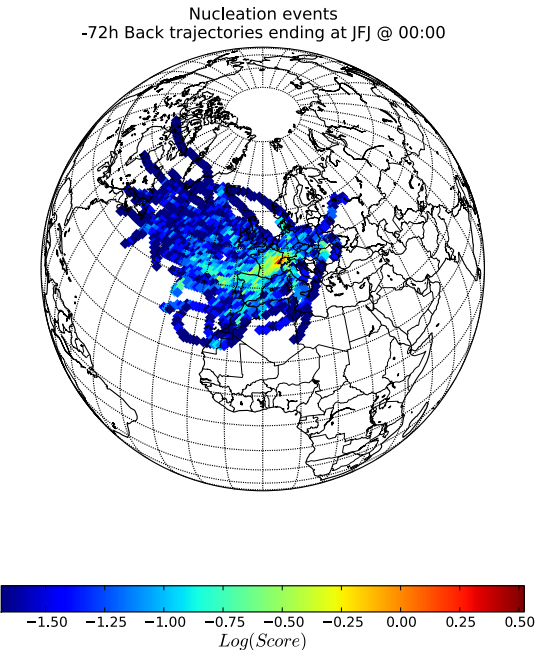

Fig. 6. Three days air mass backtrajectories ending at the measurement site at 00:00 LT for all the field campaign (right panel) and for new particle formation events (left panel). The score is the number of occurence of a given geographical position.

Table 2. New particle formation events according to air mass origin.

\begin{tabular}{lrr}
\hline $\begin{array}{l}\text { Air mass } \\
\text { origin }\end{array}$ & $\begin{array}{r}\text { Nucleation from } \\
\text { air mass origin [\%] }\end{array}$ & $\begin{array}{r}\text { Nucleation frequency } \\
\text { of the air mass [\%] }\end{array}$ \\
\hline Atlantic & 58.3 & 15.4 \\
Africa & 12.5 & 16.2 \\
Nordic & 2.1 & 10 \\
Eastern europe & 20.8 & 33.3 \\
Western europe & 6.3 & 8.6 \\
\hline
\end{tabular}

emitted from the vegetation, the absence of a preexisting condensational sink seems to be a strong condition for the occurrence of NPF events.

In the case of the Jungfraujoch, which can be described as a low preexisting condensational sink environment, the presence of condensable vapors from polluted areas (typically from Eastern Europe which is known to be an hotspot of non-methane volatile organic compounds as shown by Lanz et al., 2009) seems to prevail in the occurrence of NPF events. Eastern Europe air masses show the highest CS on NPF event days (Table 5), confirming this hypothesis. The new particle formation mecanism can also be partly examined by studying the dependency of preexisting clusters on the air mass origin, for event and non-event days. Mean size distributions are calculated before nucleation occurs (03:00-06:00 LT), and during the NPF events (09:00-12:00 LT), again under clear sky conditions, in order to exclude air mass related to cloud effects (Fig. 7a and b).

\subsubsection{Non event days}

We clearly observe from Fig. 7a, that while the cluster mode does not experience any variation according to the air mass origin, the intermediate ion mode shows a stronger variability. In fact, in Nordic air masses, the intermediate ions concentrations are highest (see Table 3) whereas in air masses from Eastern Europe, concentrations are the lowest. In other air masses, concentrations are similar one to the other. During non-event days, the size distribution of charged aerosol particles (Fig. 7a) show a weak diurnal variation in all air mass types, with higher concentrations of intermediate and large ion size classes during the afternoon compared to night. This pattern permits to quantify the increase of concentrations solely due to the updraft of charged particles or ion sources (i.e. radon) form the valley by thermally driven convection. The situation is very different for event days.

\subsubsection{Event days}

During the new particle formation event days, size distributions of ions and charged particles are very different from those of non event days even before nucleation occurs (between 03:00 and 06:00 LT, Fig. 7b), but, based on a T-test analysis, considering all events, the cluster concentration does not differ from event to non-event days prior to NPF so differences are observed for intermediate and large size classes. For atlantic and african origin the main difference is observed for intermediate ions concentration which is four times lower for event days. The situation is completely different for air masses from eastern and western europe which present a higher intermediate ions concentration for events days (respectively 13.1 and 2.6 times more). Finally, nordic air masses present a high concentration of intermediate ions 

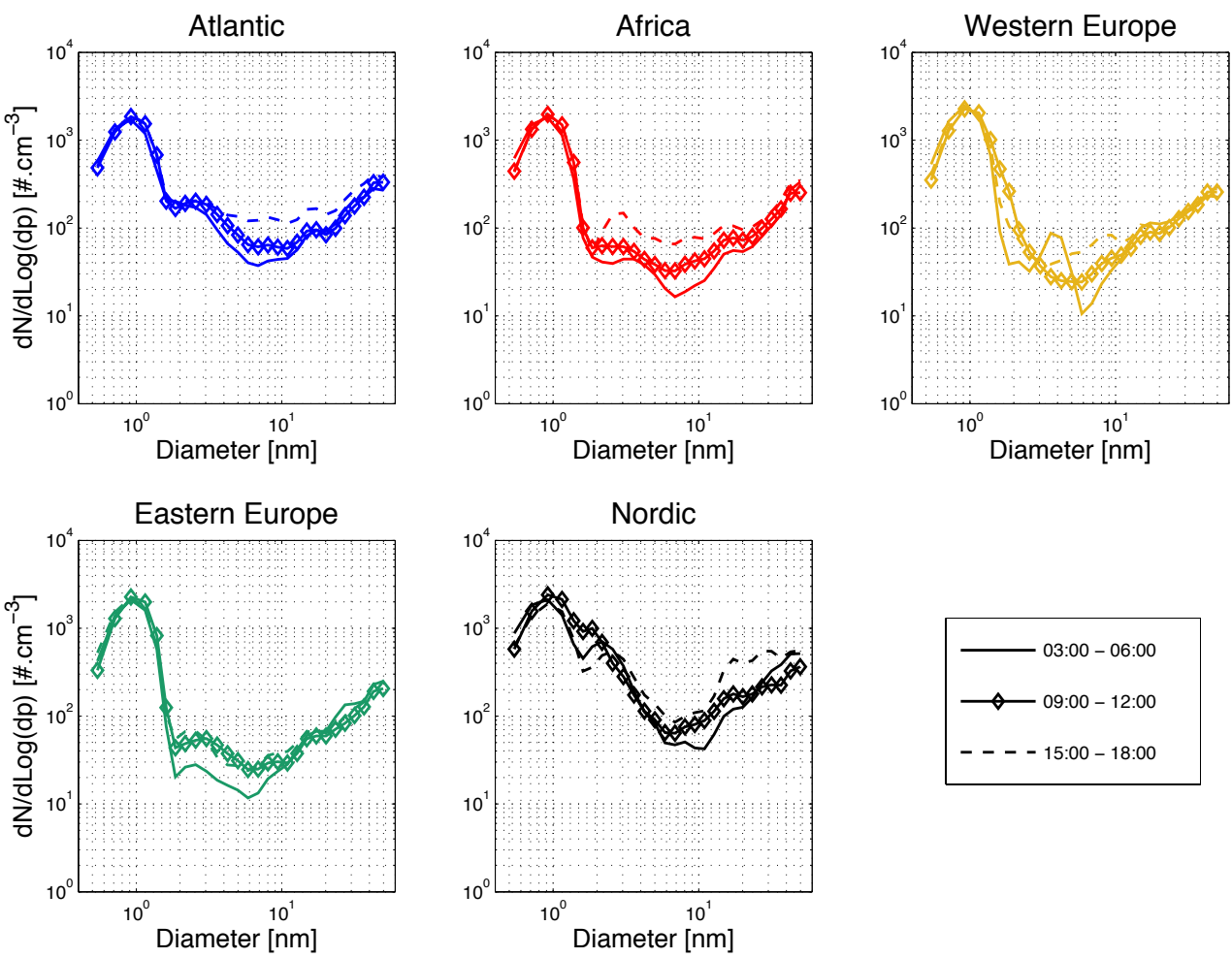

Fig. 7a. Positively charged aerosol distribution of different types of air mass origin endings at Jungfraujoch at 00:00 LT for non event days.
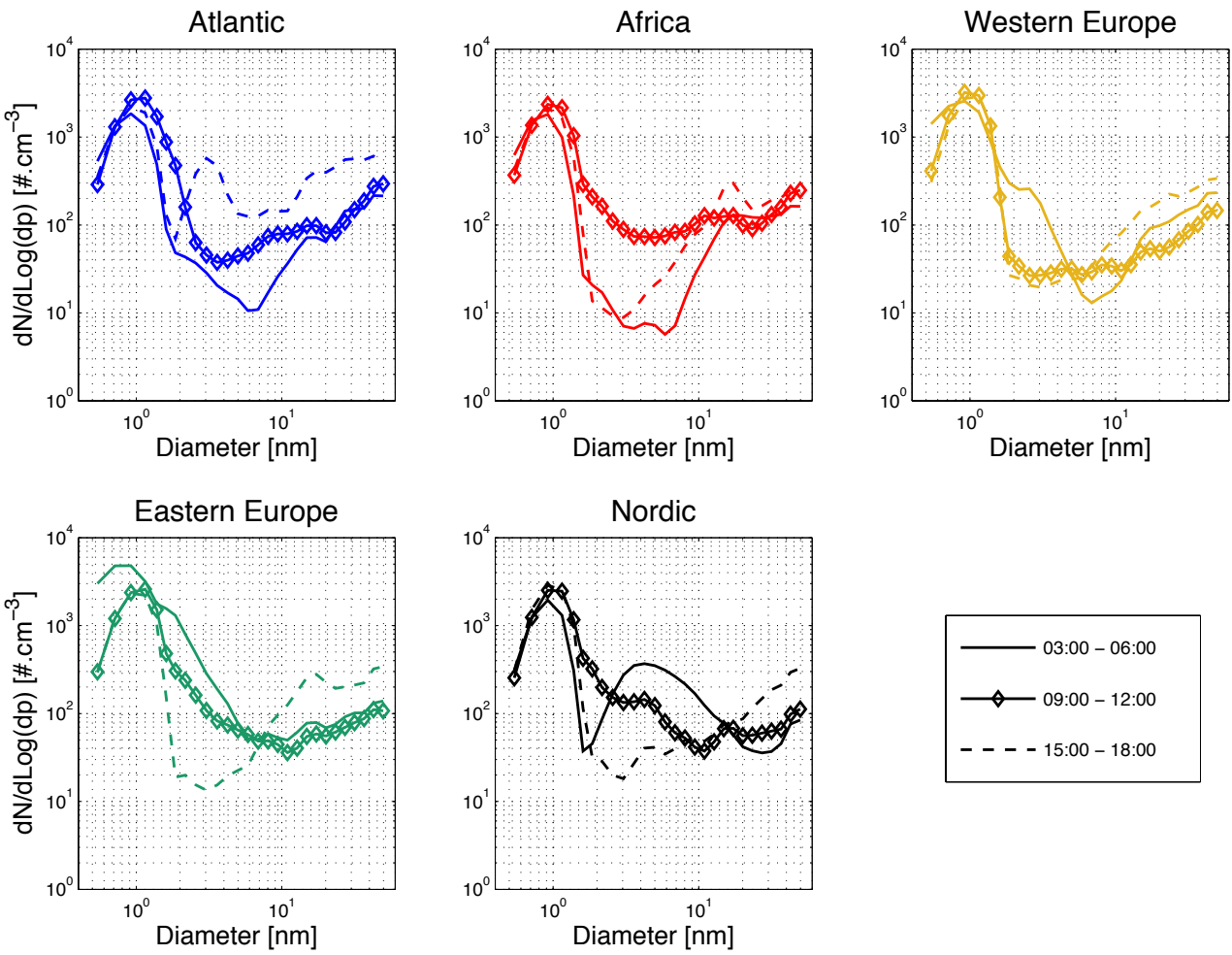

Fig. 7b. Positively charged aerosol distribution of different types of air mass origin endings at Jungfraujoch at 00:00 LT for event days. 
Table 3. Comparison of positive ion concentrations for event and non event days. Concentrations are given in [\#/ $\left.\mathrm{cm}^{-3}\right], \Delta \mathrm{Clusters}$ and $\Delta$ Large ions are computed respectively between (09:00-12:00) and (03:00-06:00), and, (15:00-18:00) and (03:00-06:00) LT. CS values are given for clear sky days.

\begin{tabular}{lrrrrr}
\hline & Atlantic & Africa & Western Europe & Eastern Europe & Nordic \\
\hline & & & Event days & & \\
Clusters (03:00-06:00) & $573 \pm 46$ & $578 \pm 76$ & $978 \pm 281$ & $2005 \pm 708$ & $524 \pm 109$ \\
$\Delta$ Clusters & $344 \pm 57$ & $196 \pm 97$ & $-15 \pm 292$ & $-1193 \pm 710$ & $262 \pm 140$ \\
$\Delta$ Large ions & $245 \pm 268$ & $68 \pm 129$ & $68 \pm 140$ & $102 \pm 26$ & $41 \pm 33$ \\
CS $\left[\times 10^{-4} \mathrm{~s}^{-1}\right]$ & $2.39 \pm 1.32$ & $2.35 \pm 2.33$ & $3.07 \pm 3.54$ & $3.80 \pm 0.67$ & ND. \\
& & & Non event days & & \\
Clusters $(03: 00-06: 00)$ & $567 \pm 68$ & $573 \pm 71$ & $730 \pm 55$ & $619 \pm 56$ & $779 \pm 278$ \\
$\Delta$ Clusters & $36 \pm 76$ & $21 \pm 81$ & $-3 \pm 63$ & $52 \pm 76$ & $121 \pm 342$ \\
$\Delta$ Large ions & $66 \pm 68$ & $41 \pm 74$ & $15 \pm 184$ & $0 \pm 219$ & $136 \pm 260$ \\
CS $\left[\times 10^{-4} \mathrm{~s}^{-1}\right]$ & $2.28 \pm 2.48$ & $3.43 \pm 4.34$ & $1.78 \pm 1.06$ & $2.69 \pm 2.45$ & ND. \\
\hline
\end{tabular}

compared to others origins for both event and non-event days. This is probably due to the fact that nucleation has already occur in these air masses which is consistent with previous work which have shown that nordic air masses favour NPF event and hence present the highest nucleation mode concentration (Sogacheva et al., 2005). Those air masses, contrarily to the other, present variation for the large ions concentration which is 2.4 times lower during event days prior to NPF.

During the new particle formation process (between 09:00 and 12:00) though, the cluster mode concentration increases by a factor $1.5 \pm 0.3$ and its geometric mean diameter shifts to larger diameters (typically from $0.8 \mathrm{~nm}$ to $1 \mathrm{~nm}$ or more) in all air masses but the Eastern Europe air masses. This result indicates that in most air masses, the formation of new clusters does occur during a NPF event.

In Eastern air masses, the pre-existing cluster concentrations are more than three times higher on event days compared to non event days, and during the NPF event no more cluster ions are formed, showing that it might be predominantly the growth of pre-existing clusters rather than nucleation of new clusters which contribute to the NPF events in eastern Europe air masses.

These observations agree with the conclusion of the study of Lehtipalo et al. (2010), in which it is shown that in some environments, NPF are driven by condensation of condensable gazes onto preexisting clusters rather than by nucleation of new clusters. Furthermore, this result can be linked to results obtained by Metzger et al. (2010) who show that the concentration of condensable vapors plays a key role in the nucleation and growth process as predicted by Kulmala et al. (2000, 2006).

After the NPF event, the intermediate ion concentrations decrease by growing to sizes beyond the upper diameter bound of the instrument. The impact of NPF on the size distribution can be evaluated by comparing the increase of large ion (which diameter is higher than $8 \mathrm{~nm}$ ) number concen- tration from 03:00-06:00 to 15:00-18:00 for non event days with the same increase during event days (Table 3). The increase of large ions concentrations is significantly higher (by a factor $2.3 \pm 1.0$ ) on event days than on non event days except when air masses come from the Nordic areas (Table 3). This is probably due to the fact that NPF linked to nordic air masses are not type I events i.e. not intense or not complete. This result reveals that new particle formation events could significantly increase the number concentration of particles in the free troposphere as already suggested by Sellegri et al. (2010). At the NCO-P station (5079 m a.s.l., Nepal), it was shown that new particle formation events occur with a frequency close to $50 \%$ of observed days and that upper free troposphere residual layer aerosol composition could be strongly influenced by NPF events.

\section{Conclusions}

The ultrafine charged aerosol concentration variability and new particle formation events were studied using a Neutral cluster and Air ion Spectrometer within the EUCAARI field campaign 2008-2009 at the Jungfraujoch research station in the Swiss Alps. Within this campaign, 309 days starting from the 9 April 2008 to the 5 May 2009 were analyzed.

A diurnal pattern of the total ions concentration, dominated by cluster ions, was found with a maximum during the day and a minimum during the night. This diurnal variation was related to the updraft of surface layer air parcels rich in preexisting particles and ion sources such as radon from the valley during the day. Cluster ion concentrations were found to be predominantly driven by radon rather than cosmic rays. The charged cluster concentration also shows a weak seasonality with minimum concentrations observed during summer, due to lower afternoon concentrations compared to winter time. This finding is likely due to the high condensational sink due to the updraft of large particles during this season and time of the day. 
Table A1. Details of nucleation characteristics. Atl. is for Atlantic and EaE. for Eastern Europe.

\begin{tabular}{lcrrrrrrr}
\hline Date & $\begin{array}{c}\text { Class of } \\
\text { event }\end{array}$ & $\begin{array}{r}\mathrm{GR}_{1.3}-3 \\
{\left[\mathrm{~nm} \mathrm{~h}^{-1}\right]}\end{array}$ & $\begin{array}{r}\mathrm{GR}_{3-7} \\
{\left[\mathrm{~nm} \mathrm{~h}^{-1}\right]}\end{array}$ & $\begin{array}{r}\mathrm{GR}_{7-20} \\
{\left[\mathrm{~nm} \mathrm{~h}^{-1}\right]}\end{array}$ & $\begin{array}{r}J_{2}^{+} \\
{\left[\mathrm{cm}^{-3} \mathrm{~s}^{-1}\right]}\end{array}$ & $\begin{array}{r}J_{2}^{-} \\
{\left[\# \mathrm{~cm}^{-3} \mathrm{~s}^{-1}\right]}\end{array}$ & $\begin{array}{r}J_{2} \\
{\left[\# \mathrm{~cm}^{-3} \mathrm{~s}^{-1}\right]}\end{array}$ & $\begin{array}{r}\text { Air mass } \\
\text { origin }\end{array}$ \\
\hline $19 / 04 / 2008$ & $\mathrm{Ib}$ & 6.8 & 9.1 & 6.3 & 0.17 & 0.21 & 2.09 & - \\
$10 / 07 / 2008$ & $\mathrm{Ia}$ & 4.2 & 3.6 & 4.4 & 0.18 & 0.28 & 2.08 & Atl. \\
$06 / 08 / 2008$ & $\mathrm{Ib}$ & 5.7 & - & - & 0.10 & 0.15 & 1.89 & Atl. \\
$30 / 08 / 2008$ & $\mathrm{Ib}$ & 6.9 & - & - & 0.21 & 0.21 & 3.84 & Atl. \\
$23 / 09 / 2008$ & $\mathrm{Ib}$ & 2.8 & 1.1 & 4.9 & 0.14 & 0.28 & 0.72 & EaE. \\
$26 / 09 / 2008$ & $\mathrm{Ib}$ & 2.0 & 1.8 & 2.3 & 0.06 & 0.14 & 1.17 & EaE. \\
$13 / 11 / 2008$ & $\mathrm{Ia}$ & 6.1 & 8 & 5.7 & 0.82 & 1.21 & 1.40 & Atl. \\
$14 / 11 / 2008$ & $\mathrm{Ib}$ & 3.2 & 3.3 & 3.6 & 0.22 & 0.38 & 1.05 & Atl. \\
$26 / 12 / 2008$ & $\mathrm{Ib}$ & 6.6 & 2.3 & 10.3 & 0.57 & 0.78 & 5.41 & EaE. \\
$20 / 01 / 2009$ & $\mathrm{Ib}$ & 6.0 & 7.1 & 8.0 & 0.18 & 0.52 & 2.03 & Atl. \\
$19 / 03 / 2009$ & $\mathrm{Ia}$ & 5.7 & 11.7 & 6.0 & 0.35 & 0.28 & 7.46 & Atl. \\
\hline
\end{tabular}

We performed a statistical analysis of new particle formation events occurrence and found that event days represent $17.5 \%$ of measured days and a seasonality pattern was pointed out with maximum of event frequency during spring and autumn and minimum during winter. This seasonality is opposite to the one of cluster ion concentrations. This is an indication that, on average, the preexisting cluster concentration is not a driving parameter for NPF events occurence. The NPF frequency is quite low compared to other sites, including high altitude sites. The site is often under cloudy conditions, which inhibit nucleation and new particle formation events, even if they promote sporadic high concentrations of cluster and intermediate ion positive and especially negative ions. When the measurement site is in cloudy conditions, we showed that the cluster ion concentrations are decreased by a factor 1.5 to 2.5 . Because cloud droplets efficiently scavenge ions and particles, and presumably because photochemistry is inhibited, NPF were observed to occur only $7.1 \%$ of the time under cloudy conditions. However, even though clouds seem to affect the frequency of NPF events, they do not drive their seasonal variation. Indeed, the seasonal variation of the frequency of NPF events is even more pronounced when considering only out-of-clouds conditions.

The ion-mediated nucleation seems to play an important role in the new particle formation process at this measurement site since ions and recombination products explain $22.3 \%$ of the particle formation.

Dependence of the event frequency on atmospheric conditions were investigated and a positive correlation was found between the NPF event occurrence and UV radiation. A weaker positive correlation was also found between nucleation event and $\mathrm{H}_{2} \mathrm{SO}_{4}$ concentration. Those results suggest that other compounds than $\mathrm{H}_{2} \mathrm{SO}_{4}$, such as organic vapors, are involved in the nucleation and subsequently growth process. A positive correlation between the NPF events frequency and the condensational sink indicates that these species are likely linked to polluted conditions and that, at
Jungfraujoch, the presence of condensing vapours is a more important parameter for NPF to occur than a low CS. NPF were also studied as a function of air mass origins according to the HYSPLIT model and we found that NPF event frequency is strongly linked to the origin of the air mass. Furthermore, two different new particle formation process were observed according to the air mass origin. For all air masses except those from Eastern Europe, event days preexisting cluster concentrations are not significantly different from non-event days concentrations, but new clusters are formed during the NPF event. On the contrary, in air masses from Eastern europe, the pre-existing cluster concentrations on event days are more than three times higher than the concentrations observed for non-event days, and during the NPF event no more cluster ions are formed, showing that it might be predominantly the growth of pre-existing clusters rather than nucleation of new clusters which contribute to the NPF events.

\section{Appendix A}

New particle formation characteristics are reported on the table below (Table A1). Only class Ia and Ib event were studied.

A T-test was performed in order to know if the difference observed on ion concentrations between positive/negative polarity, daytime/nighttime conditions or clear sky/cloudiness conditions is significant. Null hypothesis $H_{0}$ is defined as follow: the two data sets are independent random samples from normal distributions with equal means and equal but unknown variances. If $H_{0}$ is not rejected at the 5\% significance level, we assumed that there is no significant difference between the values of the mean of the two data sets $(\mathrm{T}$-test $=0)$. If $H_{0}$ is rejected at the $5 \%$ significance level, we assumed that there is a significant difference between the values of the mean of the two data sets (T-test $=1$ ). Results of different T-tests are reported on Table A2. 
Table A2. T-test results for "diurnal vs. FT" and "clear sky vs. cloudy" conditions for different size classes. a "1" indicates that a significant difference exists between the values of the mean of the two considered data sets, a " 0 " means that the observed difference is statistically non-significant.

\begin{tabular}{|c|c|c|c|c|c|c|c|c|c|c|}
\hline T-test & Jul08 & Aug08 & Sep08 & Oct08 & Nov08 & Dec08 & Jan09 & Feb09 & Mar09 & Apr09 \\
\hline \multicolumn{11}{|c|}{ Clust. } \\
\hline$D_{\text {clear }}^{+}$vs. $D_{\text {clear }}^{-}$ & 0 & 1 & 1 & 1 & 1 & 1 & 1 & 1 & 1 & 1 \\
\hline$D_{\text {clear }}^{+}$vs. $D_{\text {clear }}^{-}$ & 1 & 0 & 0 & 0 & 0 & 1 & 0 & 0 & 0 & 0 \\
\hline$D_{\text {clear }}^{+}$vs. $\mathrm{FT}_{\text {clear }}^{+}$ & 0 & 0 & 0 & 0 & 0 & 0 & 0 & 0 & 0 & 0 \\
\hline$D_{\text {clear }}^{-}$vs. FT & 1 & 1 & 1 & 1 & 1 & 1 & 1 & 1 & 1 & 1 \\
\hline$D_{\text {clear }}^{+}$vs. $\mathrm{FT}_{\text {clear }}^{+}$ & 0 & 0 & 0 & 0 & 0 & 1 & 0 & 0 & 0 & 0 \\
\hline$D_{\text {clear }}^{-}$vs. FT $\mathrm{FT}_{\text {clear }}^{-}$ & 1 & 1 & 1 & 1 & 1 & 1 & 1 & 1 & 1 & 1 \\
\hline$D_{\text {clear }}^{+}$vs. $D_{\text {clear }}^{+}$ & 0 & 0 & 0 & 0 & 0 & 0 & 0 & 0 & 0 & 0 \\
\hline$D_{\text {clear }}^{-}$vs. $D_{\text {clear }}^{-}$ & 1 & 1 & 1 & 1 & 1 & 1 & 1 & 1 & 1 & 1 \\
\hline $\mathrm{FT}_{\text {clear }}^{+}$vs. $\mathrm{FT}_{\text {clear }}^{-}$ & 1 & 1 & 1 & 1 & 1 & 1 & 1 & 1 & 1 & 1 \\
\hline $\mathrm{FT}_{\text {clear }}^{+}$vs. $\mathrm{FT}_{\text {clear }}^{-}$ & 0 & 1 & 1 & 1 & 1 & 1 & 1 & 1 & 1 & 1 \\
\hline $\mathrm{FT}_{\text {clear }}^{+}$vs. $\mathrm{FT}_{\text {clear }}^{+}$ & 0 & 0 & 0 & 0 & 0 & 0 & 0 & 0 & 0 & 0 \\
\hline $\mathrm{FT}_{\text {clear }}^{-}$vs. $\mathrm{FT}_{\text {clear }}^{-}$ & 1 & 1 & 1 & 1 & 0 & 1 & 1 & 1 & 1 & 0 \\
\hline \multicolumn{11}{|c|}{ Inter. } \\
\hline$D_{\text {clear }}^{+}$vs. $D_{\text {clear }}^{-}$ & 1 & 1 & 1 & 1 & 1 & 1 & 1 & 1 & 1 & 1 \\
\hline$D_{\text {clear }}^{+}$vs. $D_{\text {clear }}^{-}$ & 1 & 1 & 0 & 1 & 0 & 1 & 1 & 0 & 1 & 0 \\
\hline$D_{\text {clear }}^{+}$vs. FT $_{\text {clear }}^{+}$ & 0 & 0 & 0 & 0 & 1 & 0 & 0 & 1 & 0 & 1 \\
\hline$D_{\text {clear }}^{-}$vs. $\mathrm{FT}_{\text {clear }}^{-}$ & 1 & 1 & 1 & 1 & 1 & 1 & 1 & 1 & 1 & 1 \\
\hline$D_{\text {clear }}^{+}$vs. $\mathrm{FT}_{\text {clear }}^{+}$ & 1 & 1 & 1 & 1 & 1 & 1 & 1 & 1 & 1 & 1 \\
\hline$D_{\text {clear }}^{-}$Vs. FT $\mathrm{FT}_{\text {clear }}^{-}$ & 1 & 1 & 1 & 1 & 1 & 1 & 1 & 1 & 1 & 1 \\
\hline$D_{\text {clear }}^{+}$vs. $D_{c l}^{+}$ & 1 & 1 & 1 & 1 & 1 & 1 & 1 & 1 & 1 & 1 \\
\hline$D_{\text {clear }}^{-}$vs. $D_{\text {clear }}^{-}$ & 1 & 1 & 1 & 1 & 1 & 1 & 1 & 1 & 1 & 1 \\
\hline $\mathrm{FT}_{\text {clear }}^{+}$vs. $\mathrm{FT}_{\text {clear }}^{-}$ & 1 & 1 & 1 & 1 & 1 & 1 & 1 & 1 & 1 & 1 \\
\hline $\mathrm{FT}_{\text {clear }}^{+} \mathrm{vs} .^{+} \mathrm{FT}_{\text {clear }}^{-}$ & 1 & 1 & 1 & 1 & 1 & 1 & 1 & 1 & 1 & 1 \\
\hline $\mathrm{FT}_{\text {clear }}^{+}$vs. $\mathrm{FT}_{\text {clear }}^{+}$ & 0 & 1 & 1 & 1 & 1 & 0 & 0 & 1 & 1 & 1 \\
\hline $\mathrm{FT}_{\text {clear }}^{-}$vs. $\mathrm{FT}_{\text {clear }}^{-}$ & 1 & 1 & 1 & 1 & 1 & 0 & 1 & 1 & 1 & 1 \\
\hline \multicolumn{11}{|c|}{ Large } \\
\hline$D_{\text {clear }}^{+}$vs. $D_{\text {clear }}^{-}$ & 0 & 0 & 0 & 0 & 0 & 0 & 0 & 0 & 0 & 0 \\
\hline$D_{\text {clear }}^{+}$vs. $D_{\text {clear }}^{-}$ & 0 & 0 & 0 & 0 & 0 & 0 & 0 & 0 & 0 & 0 \\
\hline$D_{\text {clear }}^{+}$vs. $\mathrm{FT}_{\text {clear }}^{+}$ & 1 & 1 & 1 & 1 & 1 & 1 & 1 & 1 & 1 & 1 \\
\hline$D_{\text {clear }}^{-}$vs. $\mathrm{FT}_{\text {clear }}^{-}$ & 1 & 1 & 1 & 1 & 1 & 1 & 1 & 1 & 1 & 1 \\
\hline$D_{\text {clear }}^{+}$vs. $\mathrm{FT}_{\text {clear }}^{+}$ & 0 & 0 & 0 & 0 & 0 & 0 & 0 & 0 & 0 & 1 \\
\hline$D_{\text {clear }}^{-}$Vs. FT $\mathrm{FT}_{\text {clear }}^{-}$ & 0 & 0 & 0 & 0 & 0 & 0 & 0 & 0 & 0 & 0 \\
\hline$D_{\text {clear }}^{+}$vs. $D_{\text {clear }}^{+}$ & 1 & 1 & 1 & 1 & 1 & 1 & 1 & 1 & 1 & 0 \\
\hline$D_{\text {clear }}^{-}$vs. $D_{\text {clear }}^{-}$ & 1 & 1 & 1 & 1 & 1 & 1 & 1 & 1 & 1 & 0 \\
\hline $\mathrm{FT}_{\text {clear }}^{+}$vs. $\mathrm{FT}_{\text {clear }}^{-}$ & 0 & 0 & 0 & 0 & 0 & 0 & 0 & 0 & 0 & 0 \\
\hline $\mathrm{FT}_{\text {clear }}^{+}$vs. $\mathrm{FT}_{\text {clear }}^{-}$ & 1 & 0 & 0 & 0 & 0 & 1 & 1 & 0 & 1 & 0 \\
\hline $\mathrm{FT}_{\text {clear }}^{+}$vs. $^{+} \mathrm{FT}_{\text {clear }}^{+}$ & 1 & 0 & 1 & 0 & 1 & 0 & 1 & 0 & 1 & 1 \\
\hline $\mathrm{FT}_{\text {clear }}^{\text {clear }}$ vs. $^{-\mathrm{FT}_{\text {clear }}^{-}}$ & 0 & 0 & 0 & 0 & 0 & 0 & 0 & 0 & 0 & 0 \\
\hline
\end{tabular}


Acknowledgements. This work has been partly funded by European Commission 6th Framework program project EUCAARI, contract n036833-2 (EUCAARI). Authors thank also the NABEL network for providing gases data and MeteoSwiss for meteorological data at Jungfraujoch. NOAA Air Resources Laboratory (ARL) is acknowledged for the provision of the HYSPLIT transport and dispersion model and gdas1 data.

Edited by: M. Kulmala

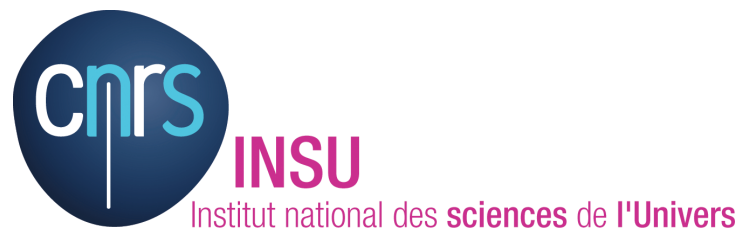

The publication of this article is financed by CNRS-INSU.

\section{References}

Alpin, K. L., Harrison, R. G., and Bennett, A. J.: Effect of the troposphere on surface neutron counter measurements, Adv. Space Res., 35(8), 1484-1491, 2005.

Arnold, F.: Multi-ion complexes in the stratosphere - implications for trace gases and aerosol, Nature, 284, 610-611, 1980.

Asmi, E., Sipilä, M., Manninen, H. E., Vanhanen, J., Lehtipalo, K., Gagné, S., Neitola, K., Mirme, A., Mirme, S., Tamm, E., Uin, J., Komsaare, K., Attoui, M., and Kulmala, M.: Results of the first air ion spectrometer calibration and intercomparison workshop, Atmos. Chem. Phys., 9, 141-154, doi:10.5194/acp-9-141-2009, 2009.

Asmi, E., Frey, A., Virkkula, A., Ehn, M., Manninen, H. E., Timonen, H., Tolonen-Kivimäki, O., Aurela, M., Hillamo, R., and Kulmala, M.: Hygroscopicity and chemical composition of Antarctic sub-micrometre aerosol particles and observations of new particle formation, Atmos. Chem. Phys., 10, 4253-4271, doi:10.5194/acp-10-4253-2010, 2010.

Baltensperger, U., Gäggeler, H. W., Jost, D. T., Lugauer, M., Schwikowski, M., Seibert, P., and Weingartner, E.: Aerosol climatology at the high-alpine site Jungfraujoch, Switzerland. J. Geophys. Res., 102(16), 19707-19715, 1997.

Baltensperger, U., Schwikowski, M., Jost, D. T., Nyeki, S., Gäggeler, H. W., and Poulida, O.: Scavenging of atmospheric constituents in mixed phase clouds at the high-alpine site Jungfraujoch part I: Basic concept and aerosol scavenging by clouds, Atmos. Environ., 32(23), 3975-3983, 1998.

Bodhaine, B. A.: Aerosol measurements at four background sites, J. Geophys. Res., 88, 10753-1768, 1983.

Boulon, J., Sellegri, K., Venzac, H., Giraud, V., Hervo, M., and Laj, P.: Investigation of the vertical extension of the nucleation process: a long term study at two different altitude sites, in preparation, 2010.

Byrd, R. H., Schnabel, R. B., and Shultz, G. A.: A trust region algorithm for nonlinearly constrained optimization, SIAM J. Numer. Anal., 24, 1152-1170, 1987.

Charlston, R. J., Langner, J., Andreae, M. O., and Warren, S. G.: Perturbation of the northern hemisphere radiative balance by backscattering from anthropogenic sulfate aerosols, Tellus Ser. A Ser B., 43, 152-163, 1991.

Collaud Coen, M., Weingartner, E., Nyeki, S., Cozic, J., Henning, S., Verheggen, B., Gehrig, R., and Baltensperger, U.: Long-term trend analysis of aerosol variables at the highalpin site Jungfraujoch, J. Geophys. Res., 112, D13213, doi:10.1029/2006JD007995, 2007.

Dal Maso, M., Kulmala, M., Lehtinen, K. E. J., Mäkelä, J. M., Aalto, P., and O'Dowd, C. D.: Condensation and coagulation sinks and formation of nucleation mode particles in coastal and boreal forest boundary layers. J. Geophys. Res., 107(D19), 8097, doi:10.1029/2001JD001053, 2002.

Dal Maso, M., Kulmala, M., Riipinen, I., Wagner, R., Hussein, T., Aalto, P. and Lethninen, K. E. J.: Formation and growth of fresh atmospheric aerosols: eight years of aerosol size distribution data from SMEAR II, Hyytil, Finland, Bor. Environ. Res., 10, 323 336, 2005.

Draxler, R. R. and Rolph, G. D.: HYSPLIT (Hybrid Single-Particle Langrangian Integrated Trajectory) Model access via NOAA ARL READY website (http://www.arl.noaa.gov/ready/hysplit4. html), NOAA Air Resources Laboratory, Silver Spring, MD, 2003.

Dunn, M. J., Jiménez, J.-L., Baumgardner, D., Castro, T., McMurry, P. H., and Smith, J. N.: Measurments of Mexico City nanoparticle size distributions: Observations of new particle formation and growth, Geophys. Res. Lett., 31, L10102, doi:10.1029/2004GL019483, 2004.

Eisele, F. L., Lovejoy, E. R., Koschiuch, E., Moore, K. F., Mauldin, R. L., Smith, J. N., McMurry, P. H., and Iida, K.: Negative atmospheric ions and their potential role in ion-induced nucleation, J. Geophys. Res., 111, D04305, doi:10.1029/2005JD006568, 2006.

Flückiger, E. O. and Bütikofer, R.: Swiss neutron monitors and cosmic ray research at Jungfraujoch. Adv. Space Res., 44(10), 1155-1159, 2009.

Forrern J., Rüttimann, R., Schneiter, D., Fischer, A., Buchmann, B., and Hofer, P.: Variability of trace gases at the high-Alpin site Jungfraujoch caused by meteorological transport process. J. Geophys. Res., 105(10), 12241-12251, 2000.

Gäggeler, H. W., Jost, D. T., Baltensperger, U., and Schwikowski, M.: Radon and thoron decay product and ${ }^{210} \mathrm{~Pb}$ measurements at Jungfraujoch, Switzerland, Atmos. Environ., 29, 607-616, 1995.

Gagné, S., Lehtpalo, K., Manninen, H. E., Franchin, A., Nieminen, T., Schobesberger, S., Ylijuuti, T., Boulon, J., Hõrrak, U., Mirme, A., Mirme, S., Sonntag, A., Asmi, E., Kulmala, M., and Petäjä, T.: Intercomparison of air ion spectrometers: a basis for interpretation, in preparation, 2010.

Hämeri, K., Kulmala, M., Aalto, P., Leszczynski, K., Visuri, R., and Hämekoski, K.: The investigations of aerosol particle formation in urban background area in Helsinki, Atmos. Res., 41, 281-298, 1996.

Harrison, R. G., Grenfell, J. L., Savage, N., Allen, A., Clemitshaw, K. C., Penkett, S., Hewitt, C. N., and Davison, B.: Observations of new particle production in the atmosphere of a moderatly polluted site in eastern England, J. Geophys. Res., D105, 1781917832, 2000.

Harrisson, R. G. and Carslaw, K. S.: Ion-Aerosol-Cloud processes in the lower atmosphere, Rev. Geophys., 41, 1012, doi:10.1029/2002RG000114, 2003.

Hirsikko, A., Bergman, T., Laakso, L., Dal Maso, M., Riipinen, I., 
Hõrrak, U., and Kulmala, M.: Identification and classification of the formation of intermediate ions measured in boreal forest, Atmos. Chem. Phys., 7, 201-210, doi:10.5194/acp-7-201-2007, 2007.

Hirsikko, A., Laakso, L., Hõrrak, U., Aalto, P. P., Kerminen, V.-M., and Kulmala, M.: Annual and size dependent variation of growth rates and ion concentrations in boreal forest. Bor. Environ. Res., 10, 357-369, 2005.

Hõrrak, U., Salm, J., and Tammet, H.: Diurnal variation in the concentration of air ions of different mobility classes in a rural area, J. Geophys. Res., 108(D20), 4653, doi:10.1029/2002JD003240, 2003.

IPCC: Intergovernmental Panel on Climate Change, Climate Change 2007 - The physical science basis: Contribution of working group I to the fourth Assessment report of the IPCC, Cambridge: Cambridge University Press, 2007.

Kulmala, M., Pirjola, L., and Mäkelä, J. M.: Stable clusters as a source of new atmospheric particles, Nature, 404(6773), 66-69, 2000.

Kulmala, M., Dal Maso, M., Mäkelä, J. M., Pirjola, L., Väkevä, M., Aalto, P., Miikkulainen, P., Hämeri, K., and O'Dowd, C.: On the formation, growth and composition of nucleation mode particles, Tellus, 53B, 479-490, 2001.

Kulmala, M., Vehkamäki, H., Petäjä, T., Dal Maso, M., Lauri, A., Kerminen, V.-M., Birmili, W., and McMurry, P. H.: Formation and growth rates of ultrafine atmospheric particles: a review of observations, J. Aerosol Sci., 35, 143-176, 2004.

Kulmala, M., Lehtinen, K. E. J., and Laaksonen, A.: Cluster activation theory as an explanation of the linear dependence between formation rate of $3 \mathrm{~nm}$ particles and sulphuric acid concentration, Atmos. Chem. Phys., 6, 787-793, doi:10.5194/acp-6-787-2006, 2006.

Kulmala, M., Riipinen, I, Sipilä, M., Manninen, H. E., Petäjä, T., Junninen, H., Dal Maso, M., Mordas, G., Mirme, A., Vana, M., Hirsikko, A., Laakso, L., Harrison, R. M., Hanson, I., Leung, C., Lehtinen, K. E. J., and Kerminen, V.-M.: Towards direct measurements of atmospheric nucleation, Science, 318, 89-92, 2007.

Kulmala, M. and Kerminen, V.-M.: On the formation and growth of atmospheric nanoparticles, Atmos. Res., 90, 132-150, doi:10.1016/j.atmosres.2008.01.005, 2008.

Kulmala, M., Asmi, A., Lappalainen, H. K., Carslaw, K. S., Pöschl, U., Baltensperger, U., Hov, Ø., Brenquier, J.-L., Pandis, S. N., Facchini, M. C., Hansson, H.-C., Wiedensohler, A., and O'Dowd, C. D.: Introduction: European Integrated Project on Aerosol Cloud Climate and Air Quality interactions (EUCAARI) - integrating aerosol research from nano to global scales, Atmos. Chem. Phys., 9, 2825-2841, doi:10.5194/acp-9-2825-2009, 2009.

Laakso, L., Mäkelä, J. M., Pirjola, L., and Kulmala, M.: Model studies on ion-induced nucleation in the atmosphere, J. Geophys. Res., 107(D20), 4427, doi:10.1029/2002JD002140, 2002.

Laaksonen, A., Kulmala, M., O’Dowd, C. D., Joutsensaari, J., Vaattovaara, P., Mikkonen, S., Lehtinen, K. E. J., Sogacheva, L., Dal Maso, M., Aalto, P., Petäjä, T., Sogachev, A., Yoon, Y. J., Lihavainen, H., Nilsson, D., Facchini, M. C., Cavalli, F., Fuzzi, S., Hoffmann, T., Arnold, F., Hanke, M., Sellegri, K., Umann, B., Junkermann, W., Coe, H., Allan, J. D., Alfarra, M. R., Worsnop, D. R., Riekkola, M. -L., Hyötyläinen, T., and Viisanen, Y.: The role of VOC oxidation products in continental new particle for- mation, Atmos. Chem. Phys., 8, 2657-2665, doi:10.5194/acp-82657-2008, 2008.

Lanz, V. A., Henne, S., Staehelin, J., Hueglin, C., Vollmer, M. K., Steinbacher, M., Buchmann, B., and Reimann, S.: Statistical analysis of anthropogenic non-methane VOC variability at a European background location (Jungfraujoch, Switzerland), Atmos. Chem. Phys., 9, 3445-3459, doi:10.5194/acp-9-3445-2009, 2009.

Lehtipalo, K., Kulmala, M., Sipilä, M., Petäjä, T., Vana, M., Ceburnis, D., Dupuy, R., and O'Dowd, C.: Nanoparticles in boreal forest and coastal environment: a comparison of observations and implications of the nucleation mechanism, Atmos. Chem. Phys., 10, 7009-7016, doi:10.5194/acp-10-7009-2010, 2010.

Lihavainen, H., Komppula, M., Kerminen, V.-M., Järvinen, H., Viisanen, Y., Lehtinen, K., Vana, M., and Kulmala, M.: Size distribution of atmospheric ions inside clouds and in cloud-free air at a remote continental site. Bor. Environ. Res., 12, 337-344, 2007.

Lovejoy, E. R., Curtius, J., and Froyd, K. D.: Atmospheric ioninduced nucleation of sulfuric acid and water, J. Geophys. Res., 109(D8), D08204/1-D08204/11, doi:10.1029/2003JD004460, 2004.

Lugauer, M., Baltensperger, U., Furger, M., Gäggeler, H. W., Jost, D. T., Nyeki, S., and Schwikowski, M.: Influences of vertical transport and scavenging on aerosol particle surface area and radon decay product concentrations at the Jungfraujoch (3454 m above the seal level), J. Geophys. Res., 105(15), 19869-19879, 2000.

Mäkelä, J. M., Aalto, P., Jokinen, V., Pohja, T., Nissinen, A., Palmroth, S., Markkanen, T., Seitsonen, K., Lihavainen, H., and Kulmala, M.: Observations of ultrafine aerosol particle formation and growth in boreal forest, Geophys. Res. Lett., 24, 1219-1222, 1997.

Manninen, H. E., Nieminen, T., Riipinen, I., Yli-Juuti, T., Gagné, S., Asmi, E., Aalto, P. P., Petäjä, T., Kerminen, V.-M., and Kulmala, M.: Charged and total particle formation and growth rates during EUCAARI 2007 campaign in Hyytiälä, Atmos. Chem. Phys., 9, 4077-4089, doi:10.5194/acp-9-4077-2009, 2009.

Manninen, H. E., Nieminen, T., Asmi, E., Gagné, S., Häkkinen, S., Lehtipalo, K., Aalto, P., Kivekäs, N, Vana, M., Mirme, A., Mirme, S., Hõrrak, U., Plass-Dülmer, C., Stange, G., Kiss, G., Hoffer, A., Moerman, M., Henzing, B., Brinkenberg, M., Kouvarakis, G. N., Bougiatioti, K., O’Dowd, C., Ceburnis, D., Arneth, A., Svenningsson, B., Swietlicki, E., Tarozzi, L., Decesari, S., Sonntag, A., Birmili, W., Wiedensohler, A., Boulon, J., Sellegri, K., Laj, P., Baltensperger, U., Laaksonen, A., Joutsensaari, J., Petäjä, T., Kerminen, V.-M. and Kulmala, M.: EUCAARI ion spectrometer measurements at 12 European sites - analysis of new particle formation events. Atmos. Chem. Phys., 10, 79077927, doi:10.5194/acp-10-7907-2010, 2010.

Metzeger, A., Verheggen, B., Dommen, J., Duplissy, J., Prevot, A. S. H., Weingartner, E., Riipinen, I., Kulmala, M., Spracklen, D. V., Carslaw, K. S., and Baltensperger, U.: Evidence for the role of organics in aerosol particle formation under atmospheric conditions, P. Natl. Acad. Sci. USA, 107, 6646-6651, doi:10.1073/pnas.0911330107, 2010.

Mirme, A., Tamm, A., Mordas, G., Vana, M., Uin, J., Mirme, S., Bernotas, T., Laakso, L., Hirsikko, A., and Kulmala, M.: A wide range multi-channel Air Ion Spectrometer. Bor. Env. Res., 12, 247-264, 2007. 
Mirme, S., Mirme, A., Minikin, A., Petzold, A., Hõrrak, U., Kerminen, V.-M., and Kulmala, M.: Atmospheric sub-3 nm particles at high altitudes, Atmos. Chem. Phys., 10, 437-451, doi:10.5194/acp-10-437-2010, 2010.

Nadykto, A. B. and Yu, F.: Formation of binary ion clusters from polar vapours: effect of the dipole-charge interaction, Atmos. Chem. Phys., 4, 385-389, doi:10.5194/acp-4-385-2004, 2004.

Nishita, C., Osada, K., Kido, M., and Matsunaga, K.: Nucleation mode particles in upslope valley winds at Mount Norikura, Japan: Implications for the vertical extent of new particle formation events in the lower troposphere, J. Geophys. Res., 113, D06202, doi:10.1029/2007JD009302, 2008.

Nyeki, S., Li, F., Weingartner, E., Streit, N., Colbeck, I., Gäggeler, H. W., and Baltensperger, U.: The background aerosol size distribution in the free troposphere: An analysis of the annual cycle at a high-alpine site, J. Geophys. Res., 103, 31749-31762, 1998.

O’Dowd, C. D., Geever, M., Hill, M. K., Smith, M. H., and Jennings, S. G.: New particle formation: Nucleation rates and spatial scales in the clean marine coastal environment. Geophys. Res. Lett., 25, 1661-1664, 1998.

Paasonen, P., Sihto, S.-L., Nieminen, T., Vuollekoski, H., Riipinen, I., Plaß-Dülmer, C., Berresheim, H., Birmili, W., and Kulmala, M.: Connection between new particle formation and sulfuric acid at Hohenpeissenberg (Germany) including the influence of organic compounds, Bor. Environ. Res., 14, 616-629, 2009.

Petäjä, T., Mauldin, III, R. L., Kosciuch, E., McGrath, J., Nieminen, T., Paasonen, P., Boy, M., Adamov, A., Kotiaho, T., and Kulmala, M.: Sulfuric acid and $\mathrm{OH}$ concentrations in a boreal forest site, Atmos. Chem. Phys., 9, 7435-7448, doi:10.5194/acp9-7435-2009, 2009.

Sellegri, K., Laj, P., Venzac, H., Boulon, J., Picard, D., Villani, P., Bonasoni, P., Marinoni, A., Cristofanelli, P., and Vuillermoz, E.: Seasonal variations of aerosol size distributions based on long-term measurements at the high altitude Himalayan site of Nepal Climate Observatory-Pyramid (5079 m), Nepal, Atmos. Chem. Phys. Discuss., 10, 6537-6566, doi:10.5194/acpd10-6537-2010, 2010.

Shaw, G. E.: Aerosols at a mountaintop observatory in Arizona, J. Geophys. Res., 112, D07206, doi:10.1029/2005JD006893, 2007.

Sogacheva, L., Dal Maso, M., Kerminen, V.-M., and Kulmala, M.: Probability of nucleation events and aerosol particle concentration in different air mass types arriving at Hyytiälä, souther Finland, based on back trajectories analysis, Bor. Environ. Res., 10, 479-491, 2005.

Stanier, C. O., Khlystov, A. Y., and Pandis, S. N.: Nucleation events during the Pittsburgh air quality study: Description and relation to key meteorological, gas phase, and aerosol parameters, Aerosol Sci. Tech., 38, 253-264, 2004.

Suni, T., Kulmala, M., Hirsikko, A., Bergman, T., Laakso, L., Aalto, P. P., Leuning, R., Cleugh, H., Zegelin, S., Hughes, D., van Gorsel, E., Kitchen, M., Vana, M., Hõrrak, U., Mirme, S., Mirme, A., Sevanto, S., Twining, J., and Tadros, C.: Formation and characteristics of ions and charged aerosol particles in a native Australian Eucalypt forest, Atmos. Chem. Phys., 8, 129-139, doi:10.5194/acp-8-129-2008, 2008.

Rodríguez, S., González, Y., Cuevas, E., Ramos, R., Romero, P. M., Abreu-Afonso, J., and Redondas, A.: Atmospheric nanoparticle observations in the low free troposphere during upward orographic flows at Izaña Mountain Observatory, Atmos. Chem.
Phys., 9, 6319-6335, doi:10.5194/acp-9-6319-2009, 2009.

Tammet, H.: Size and mobility of nanoparticles, clusters and ions, J. Aerosol Sci., 26, 459-475, 1995.

Tammet, H. and Kulmala, M.: Simulation tool for atmospheric aerosol nucleation bursts, J. Aerosol Sci., 36, 173-196, 2005.

Tunved, P., Nilsson, E. D., Hansson, H.-C., Ström, J., Kulmala, M., Aalto, P., and Viisanen, Y.: Aerosol characteristics of air masses in northern Europe: Influences of location, transport, sinks, and sources, J. Geophys. Res., 110, D07201, doi:10.1029/2004JD005085, 2005.

Twomey, S.: Pollution and the planetary albedo, Atmos. Environ., 8, 1251-1256, 1974.

Usoskin, I. G. and Kosvaltsov, G. A.: Cosmic rays and climate of the Earth: Possible connection?, C.R. Geoscience, 340, 441-450, 2008.

Venzac, H., Sellegri, K., and Laj, P.: Nucleation events detected at the high altitude site of the Puy de Dôme research station, France, Bor. Environ. Res., 12, 345-359, 2007.

Venzac, H.: Étude des processus de nucléation dans l'atmosphère, PhD. thesis, 2008.

Venzac, H., Sellegri, K., Laj, P., Villani, P., Bonasoni, P., Marioni, A., Cristofanelli, P., Calzolari, F., Fuzzi, S., Decesari, S., Facchini, M.-C., Vuillermoz, E., and Verza, G.-P.: High frequency new particle formation in the Himalayas, P. Natl. Acad. Sci. USA, 105, 15666-15671, 2008.

Weber, R. J., McMurry, P. H., Eisele, F. L., and Tanner, D. J.: Measurements of expected nucleation precursor species and 3 to 500 nm diameter particles at Mauna Loa Observatory, Hawaï, J. Atmos. Sci., 52, 2242-2257, 1995.

Weber, R. J., Marti, J. J., McMurry, P. H., Eisele, F. L., Tanner, D. J., and Jefferson, A.: Measurements of new particle formation and ultrafine growth rates at a clean continental site, J. Geophys. Res., 102(D4), 4375-4285, 1997.

Weber, R. J., Orsini, D., Wang, B., Scheuer, E., Talbot, R. W., Dibb, J. E., Seid, G. K., DeBell, L., Mauldin, R. L., Koschiuch, E., Cantrell, C., and Eisele, F.: Investigations into free tropospheric new particle formation in the central Canadian arctic during the winter/spring transition as part of TOPSE, J. Geophys. Res., 108(D4), 8357, doi:10.1029/2002JD002239, 2003.

Weingartner, E., Nyeki, S., and Baltensperger, U.: Seasonal and diurnal variation of aerosol size distributions $(10<D<750 \mathrm{~nm})$ at a high-alpine site (Jungfraujoch $3580 \mathrm{~m}$ a.s.1.). J. Geophys. Res., 104(21), 26809-26820, 1999.

Woo, K. S., Chen, D. R., Pui, D. Y. H., and McMurry, P. H.: Measurements of Atlanta aerosol size distributions: Observations of ultrafine particle events, Aerosol Sci. Tech., 34, 75-87, 2001.

Yu, F. and Turco, R. P.: From molecular clusters to nanoparticles: Role of ambient ionization in tropospheric aerosol formation, J. Geophys. Res., 106, 4797-4814, 2001.

Yu, F., Wang, Z., Luo, G., and Turco, R.: Ion-mediated nucleation as an important global source of tropospheric aerosols, Atmos. Chem. Phys., 8, 2537-2554, doi:10.5194/acp-8-2537-2008, 2008.

Zellweger, C., Ammann, M., Buchmann, B., Hofer, P., Lugauer, M., Rüttimann, R., Streit, N., Weingartner, E., and Baltensperger, U.: Summertime $\mathrm{NO}_{\mathrm{y}}$ speciation at the Jungfraujoch, $3580 \mathrm{~m}$ above the sea level, Switzerland, J. Geophys. Res., 105(5), 6655-6667, 2000 . 